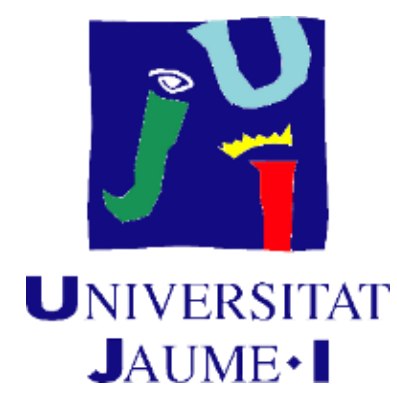

\title{
Influence of Celebrity Endorsement on Mature Female Luxury Cosmetic Consumers
}

\author{
By
}

PhD Student: Leonor Alberola Amores

PhD Director: Dra. Dña. Susana Miquel Segarra

PhD Co-Director: Dra. Dña. Irene García Medina

Castellón, 10th September 2020 



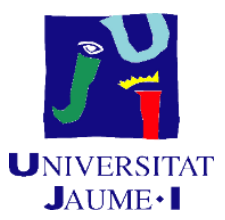

\author{
Programa de Doctorat en / Programa de Doctorado en \\ Ciencias de la Comunicación \\ Escola de Doctorat de la Universitat Jaume I / Escuela de \\ Doctorado de la Universitat Jaume I
}

Influence of Celebrity Endorsement on Mature Female Luxury Cosmetic Consumers.

\begin{abstract}
Influencia del "celebrity endorsement" en consumidoras de cosméticos de lujo para mujeres maduras
\end{abstract}

Memòria presentada per Leonor Alberola Amores per a optar al grau de doctor/a per la Universitat Jaume I Memoria presentada por Leonor Alberola Amores para optar al grado de doctor/a por la Universitat Jaume I

Leonor Alberola Amores

Dra. Susana Miquel

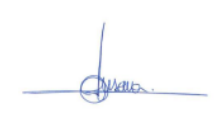

Dra. Irene García Medina

Castelló de la Plana, 28th diciembre 2020 



\section{Financiación}

La presente tesis no ha recibido financiación de agencias financiadoras públicas o privadas ni ha habido contrato predoctoral del doctorando/a. 



\section{Acknowledgements}

I want to express my thanks to my two supervisors, Susana Miquel Segarra of Jaume I University and Irene Garcia Medina of Glasgow Caledonian University, as well as to my tutor Carlos Fanjul, of Jaume I University.

They were amazing to support me and help me through the whole process of writing my PhD thesis.

I also want to thank my family, especially my mother, Carmen, who was always there for me even in the worst moments. 



\section{CONTENTS}

ABSTRACT \& KEYWORDS (ENGLISH/SPANISH/VALENCIÀ) ...............................

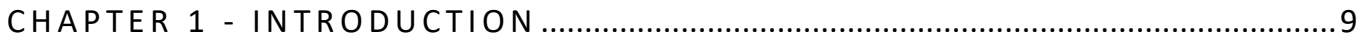

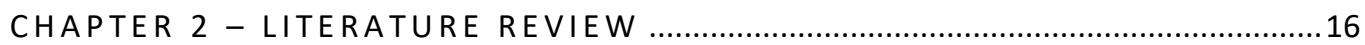

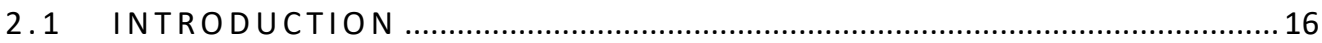

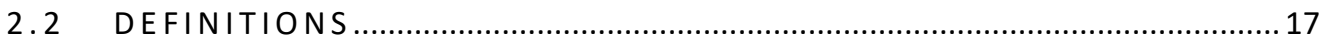

2.3 LUXURY COSMETIC INDUSTRY AND CELEBRITY ENDORSEMENt ...19

2.4 CREDIBILITY, CONGRUENCE AND TRANSFERENCE ............................22

2.5. SOCIAL MEDIA AND CELEBRITY ENDORSEMENT …............................. 28

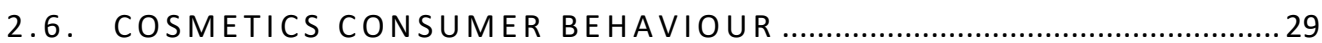

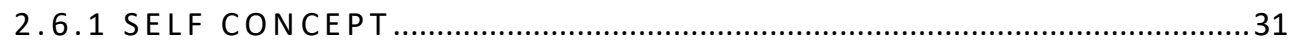

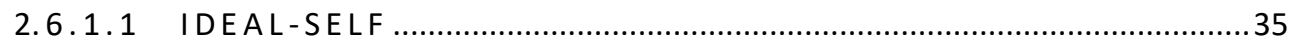

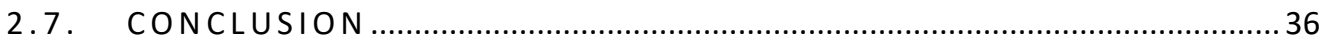

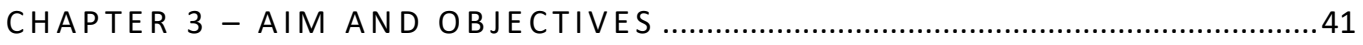

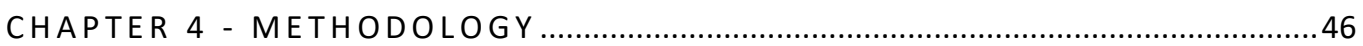

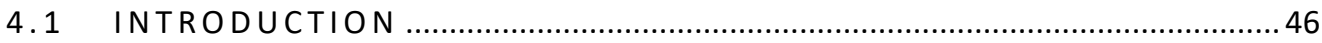

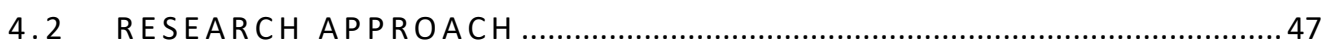

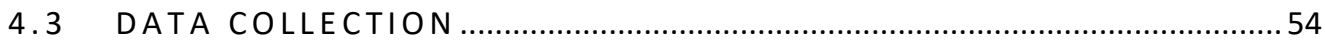

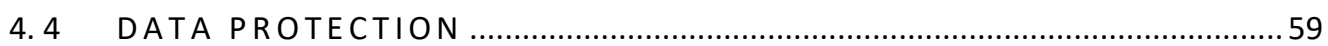

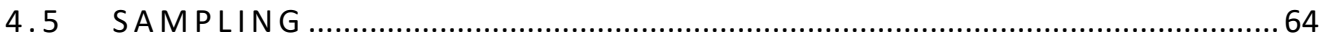

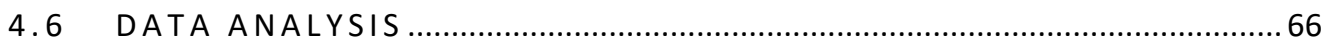




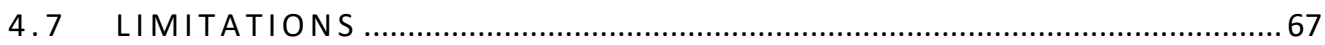

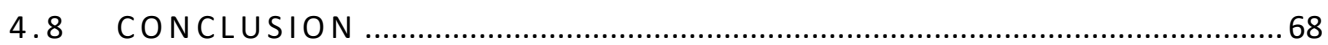

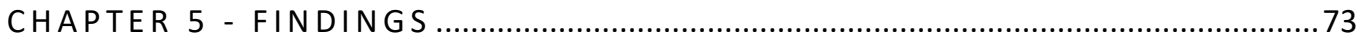

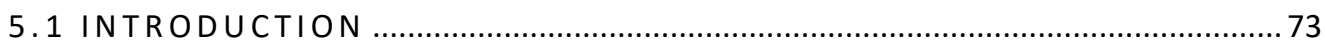

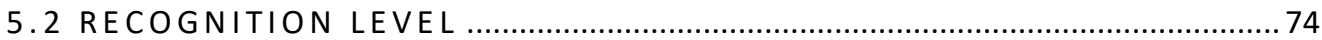

5.3 FEATURES OFCELEBRITY ENDORSEMENT ............................................. 80

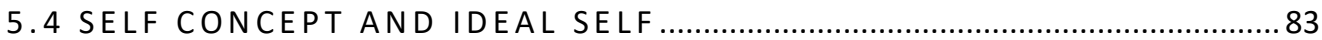

5.5 SELF CONCEPT CLARITY MODEL ........................................................... 85

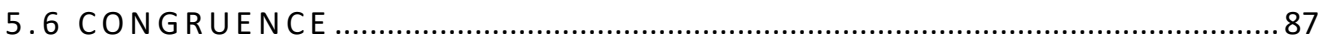

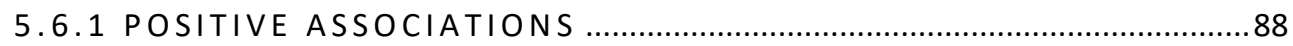

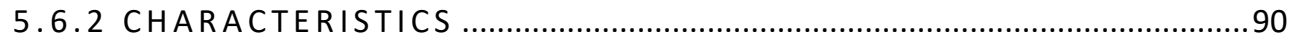

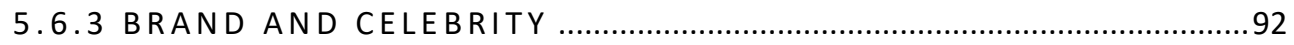

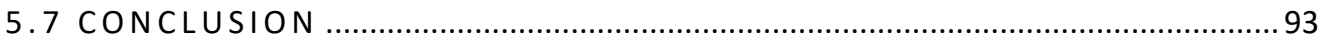

CHAPTER 6 - CONCLUSIONS, LIMITATIONS AND RECOMMENDATIONS ....99

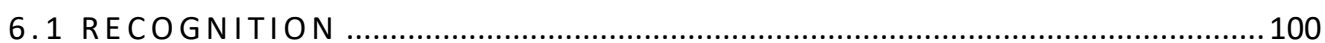

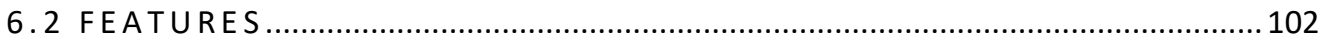

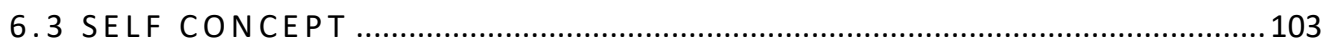

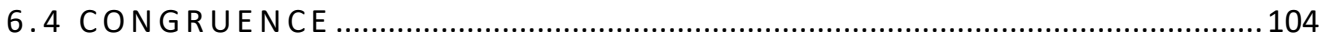

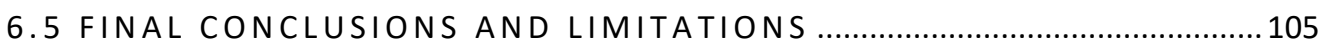

6.6 CONCLUSIONES FINALES Y LIMITACIONES ............................................ 107

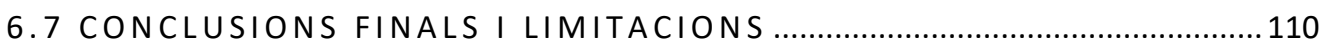

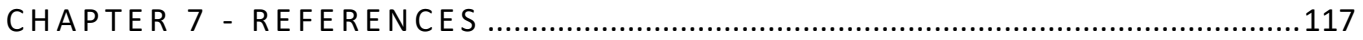

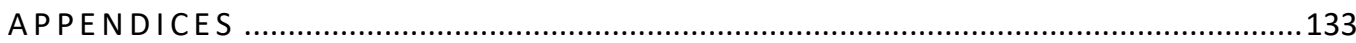


APPENDIX B: STRUCTURE OF ONLINE SURVEY 
ABSTRACT \& KEYWORDS 


\title{
ABSTRACT \& KEYWORDS (ENGLISH/SPANISH/VALENCIÀ)
}

\begin{abstract}
Globally, luxury cosmetic brands employ celebrity endorsement as a tool for building credibility with existing and potential end users. There is certainly a significant body of knowledge on celebrity endorsers, their credibility markers, and how they affect subliminal changes in the buying behaviour of customers. Departing from such past practice, this study aims to undertake a systematic analysis of the influence of celebrity endorsements on mature women, aged 40-60, using a combination of qualitative and quantitative methods like online questionnaires and structured interviews, apart from an exhaustive review of relevant literature on the subject.
\end{abstract}

The researcher did not come across any evidence to suggest that celebrity endorsement exerted any major influence on mature female consumers. Even so, the research did not completely rule out the scope and play of celebrity endorsers in this market segment. By effectively altering the messaging and imagery, it was certainly possible to make the right connections with this user market. For instance, the study revealed that mature female consumers were more likely to relate to an ad featuring celebrities of similar age as themselves and who are actual users of the product. 
Further research on a larger sample size will, sure enough, help the researcher to formulate stronger and workable concepts for the mature female consumer market in order to understand it better.

Key words: Celebrity endorsement, luxury cosmetic brands, mature female consumers, social media 


\section{Resumen}

A nivel mundial, las marcas de cosméticos de lujo emplean el celebrity endorsement como una herramienta para generar credibilidad entre usuarias existentes y potenciales. Aunque ya existen estudios sobre la influencia de los celebrity endorsement, sus marcadores de credibilidad y cómo afectan a los cambios subliminales en el comportamiento de compra de los clientes, no hay estudios específicos efectuados sobre mujeres en edad madura. Partiendo de esto, este estudio tiene como objetivo emprender un análisis sistemático de la influencia del celebrity endorsement en mujeres maduras, de 40 a 60 años, utilizando una combinación de métodos cuantitativos y cualitativos como cuestionarios en línea y entrevistas estructuradas, además de una revisión exhaustiva de literatura relevante sobre el tema.

El investigador no encontró ninguna evidencia que sugiera que el celebrity endorsement ejerciera una influencia importante en las consumidoras maduras. Aun así, la investigación no descarta por completo el alcance y el juego de los celebrity endorsement en este segmento de mercado. Al alterar de manera efectiva los mensajes y las imágenes, es posible establecer las conexiones correctas con este mercado de usuarias. Por ejemplo, el estudio reveló que las consumidoras maduras eran más propensas a relacionarse con un anuncio con celebridades de edades similares a ellas y que son usuarias reales del producto.

Una investigación adicional sobre un tamaño de muestra más grande, sin duda, ayudaría al investigador a formular conceptos más 
sólidos y viables para el mercado de consumo femenino maduro con el fin de comprenderlo mejor.

Palabras clave: Celebrity endorsement, marcas de cosméticos de lujo, consumidoras maduras, redes sociales 


\section{Resum:}

En l'àmbit mundial, les marques de cosmètics de luxe empren el "celebrity endorsement" com una eina per a generar credibilitat entre usuàries existents i potencials. Encara que ja existeixen estudis sobre la influència dels "celebrity endorsement", els seus marcadors de credibilitat i com afecten els canvis subliminals en el comportament de compra dels clients, no hi ha estudis específics efectuats sobre dones en edat madura. Partint d'això, aquest estudi té com a objectiu emprendre una anàlisi sistemàtica de la influència del "celebrity endorsement" en dones madures, de 40 a 60 anys, utilitzant una combinació de mètodes quantitatius i qualitatius com a qüestionaris en línia i entrevistes estructurades, a més d'una revisió exhaustiva de literatura rellevant sobre el tema.

L'investigador no va trobar cap evidència que suggerisca que el "celebrity endorsement" exercira una influència important en les consumidores madures. Així i tot, la investigació no descarta per complet l'abast i el joc dels "celebrity endorsement" en aquest segment de mercat. En alterar de manera efectiva els missatges $i$ les imatges, és possible establir les connexions correctes amb aquest mercat d'usuàries. Per exemple, l'estudi va revelar que les consumidores madures eren més propenses a relacionar-se amb un anunci amb celebritats d'edats similars a elles i que són a més a més usuàries reals del producte.

Una investigació addicional sobre una grandària de mostra més gran, sens dubte, ajudaria l'investigador a formular conceptes més sòlids i viables per al mercat de consum femení madur amb la finalitat de comprendre-ho millor. 
Paraules clau: Celebrity endorsement, marques de cosmètics de luxe, consumidores madures, xarxes socials 
INTRODUCTION 


\section{CHAPTER 1 - INTRODUCTION}

This thesis primarily aims to perform a critical examination of whether or not the purchasing decisions of "mature women" in the 40-60 demographic around luxury cosmetics are influenced by celebrity endorsements and, if so, to what extent.

The study is set in the context of UK's luxury cosmetic industry pegged at $f 7,6$ billion (IBIS, 2019) and easily one of the country's largest markets. In the United Kingdom, income in 2018 was $f 14.2$ billion. (Caldwell, 2019). The market participants include the who's who of the luxury cosmetics space like Chanel, Dior and Givenchy (GlobalData, 2019), all vying for the mind space and wallets of à la mode and image conscious consumers. The offerings include a miscellany ranging from foundations and mascara to haircare products like shampoo and dye. In addition, in a hypercompetitive market, marketers are making an ongoing effort to improve their formula and ingredients (CTPA, 2019). Seventy two per cent of consumers considered that the luxury cosmetics products they utilise improve their quality of life (Creek et al, 2017).

Contemporary research is centred for the most part on the buying behaviour of female luxury cosmetics users in the 25-40 segment. However, UK alone boasts more than 9 million women consumers in the $40+$ demographic, and the potential influences on this market certainly deserve careful consideration by market researchers (Mintel, 2019). Given the compelling size of this market segment, it is critical that luxury cosmetics brands ensure their products are not only within easy reach of their intended end users 
but are also able to have a positive effect on their purchase decision (Hudders et al., 2013).

A 'celebrity endorser' is any individual easily recognisable by the general public and leverages this visibility and goodwill to either appear alongside the product in an ad or furthermore endorse the product. Celebrity endorsement over the years has emerged as a widespread and firmly implanted marketing strategy in the cosmetic industry (McCracken, 1989). The past decades have seen several products being endorsed by celebrities on television and in print ads. Hollywood icon Monica Bellucci' endorsement for Dior and actress Liv Tyler's for Givenchy (Dior, 2011; Givenchy, 2014) are just some of the notable examples. In more recent times, there has been a virtual explosion of celebrity endorsements of every possible kind and across a plethora of social media platforms including Facebook, and Instagram (Macdonald et al., 2016). The campaigns using celebrities search to persuade showing attributes of the famous people involved (Centocchi, 2007).

As mentioned earlier, previous research (Tantiseneepong, et al., 2012) has limited itself for the most part to the influence of celebrity endorsement on relatively younger consumers. Also, there are general studies (Luppe, et al., 2020) but not many explicitly regarding mature females.

Celebrity marketing campaigns are known to exercise a positive influence on their buying decisions, not quite surprising since younger consumers build their self-image after celebrities and their style and appearance are more often than not influenced by megastars (Kastanakis et al., 2012). 
By contrast, with limited research in literature on mature female consumers, the extent of the influence exerted by celebrity endorsement on this segment is a matter of conjecture.

What are the plausible distinguishing features of a certain celebrity that might cause these buyers to move one step closer in their cognitive journey towards the brand? What kind of celebrities carry more credibility and vibe better with mature female consumers? This is a fairly sizable target market and therefore it becomes all the more important for brands to lift the current fog and develop a coherent understanding of it in order to be able to tailor an effective celebrity endorsement strategy, a key element of which consists in picking the "right" endorser who can successfully engage the market (Moraes, et al., 2019). As previously stated, the need for a study of this nature arises from a lack of pre-existing research. 
LITERATURE REVIEW 


\subsection{INTRODUCTION}

The chapter surveys contemporary literature on celebrity endorsement. At the outset, it describes the phenomenon of celebrity endorsement, its nature and scope, and then undertakes a fairly detailed investigation of how it correlates with consumer behaviour. The chapter concludes with a detailed examination of luxury cosmetics industry as evidenced in UK and role of celebrity endorsement as a marketing stimulus with special reference to female consumers aged 40-60. 
Back in 1989, McCracken defined 'celebrity' as someone who has become popular by virtue of being occupied in domains like for example cinema, or television. With time, advent of social media, and a general shift of social interests in general, the term has broadened in meaning so much so that there are now alternative routes to becoming a celebrity.

The result is that even someone who is not a high-profile actor or sportsperson or without any other 'special achievement' can turn into a celebrity provided she/he can garner public interest (Marshall \& Redmond, 2016). Due to changes in the terminology, businesses can now pick and choose from a large and rather mixed bag of celebrities to endorse diverse brands (Hollensen \& Schimmelpfennig, 2013).

Celebrity endorsement is the promotion of a product or service by a person who is widely known and uses such public recognition to appear with service or a product in an ad, in effect, giving it her/his seal of approval (Dwivedi et al., 2015). Seno \& Lukas, (2007) explained that there are different types of celebrity endorsement: explicit, implicit, co-representational and imperative.

In explicit celebrity endorsement, the endorsers call out the brand or product they are supporting. Implicit endorsement throws hints that the celebrity pictured in the ad is in the habit of using the endorsed product without directly expressing the same. Such tacit endorsement encourages consumers into trying the product to 
benefit from the same privileged experience as the celebrity, according to Seno and Lukas (2007). In this class of endorsement, consumers see the celebrity using the product, which seems their preferred option as evidenced by extensive research carried out by Knoll and Matthes (2016). Even so, more research is still needed to figure out what type of celebrity endorsement is more influential vis-a-vis different types of brands and when advertising to various demographics (Pradahan, et al., 2016).

Celebrities are also in the practice of telling consumers to utilize certain products, a method termed as imperative celebrity endorsement. Last but no less important is co-representational advertisement where the celebrity appears only alongside the endorsed product (Seno \& Lukas, 2007).

The mileage celebrity endorsement gives brands has been highlighted time and again by several authors (Sääksjärvi et al., 2015). In comparison with the competition, brands that employ celebrity endorsement can enhance their products' standing, improve consumers' product and brand recall, and, in the final analysis, trigger good consumer attitudes towards the brand (Sääksjärvi et al., 2015). 
A cosmetic, for the purpose of this discussion, is any substance or mixture intended to be placed in contact with the various external parts of the human body, as per Article II of the EU Cosmetics Industry Regulation. This encompasses skin care, hair care, colour cosmetics, fragrances and oral care segments (CosmeticsEurope, 2019).

In the sector of cosmetic, a luxury brand can be defined as an impression in the mind of the consumer that could associate the brand with high levels of price, quality, aesthetics and exclusivity (Heine, 2012).

Celebrity endorsement is one of Europe's top five sectors. It is also a famous marketing device in the luxury cosmetics industry.

The market for makeup is a burgeoning one, providing a wide and ever-growing portfolio of products (Mintel, 2019). The market has grown by $9 \%$ in 2018 in the UK, buoyed by makeup trends like colour-correction.

The top luxury brands in the UK market are, not surprisingly, global giants like Chanel, Dior, Givenchy, Yves Saint Laurent, Estee Lauder. 
Celebrity endorsement is a well-established advertising tool method used by a quarter of all advertisers worldwide. Top-of-thepack luxury brands in cosmetic industry (the likes of Chanel, Dior and Givenchy) lavishly indulge in celebrity endorsement (Ingavale, 2016). This helps them architect a strong brand image in the eyes of end users, a result due in large to the transference of the endorser's trustworthiness to the brand she/he backs (Hodge, 2015). Studies show that multiple factors, like the celebrity's attractiveness, trustworthiness, and perceived expertise, tend to weigh with buyers, which makes it all the more important that brands exercise a lot of care to handpick the right endorser who can carry the message effectively and cogently to consumers (Choi \& Rifon, 2012).

In the current century, people are aware of image manipulation techniques, like Photoshop and editing, widely used to make celebrities look unblemished and unrealistic (Hoffman, 2007). Since customers are more informed than ever before, brands are increasingly choosing a whole new path, namely, running highly realistic campaigns that celebrate age rather than anti-ageing as well as natural appearances and beauty.

L'Oréal Paris (2016) was among the first to taste success with a campaign of this kind. Such endorsements vibe much better with women in the 40-60 age group as these urge them to embrace their age and be proud of their mature looks. This brings focus and discussion on whether luxury cosmetics brands should choose celebrity endorsers whose age correspond to that of their target market, which would make them more relatable for these consumers (LaWare \& Moutsatsos, 2013). 
On the contrary, a greater part of research indicates that it is with younger audiences that celebrity endorsement produces the most result (Hugosson, 2014). According to this author, the celebrity's attractiveness works better with the younger age groups while older demographics lay more stress on the expertise level and credibility of the endorser. Celebrity-endorsed cosmetics create a more positive feeling with consumers in the 15-34 demographic, and they are more likely to buy the brand as a consequence. 
The credibility (quality of being trusted) of a celebrity step up her/his effectiveness as an endorser. Source credibility is the people's perception of the expertise, trustworthiness and attractiveness of the celebrity in question (Munnukka et al., 2016). Various authors on different occasions have considered different aspects of credibility that they think are most important.

Spry et al. (2011) are of the view that a credible celebrity endorser can have a good impact on the endorsed product. In their view, consumers believe the credibility of the celebrity and this credibility transfers to the product, thus making the product credible in their eyes, in turn helping to augment the consumers' valuation of the brand and building brand equity. This credibility is of enormous importance for the customer's acceptation of the product (Zapata \& Martinez Cairo, 2016). On the contrary, a celebrity endorser who fails to convince the end audience could potentially drive consumers away from the brand, and this can possibly happen in instances where more than one product is endorsed by the self-same celebrity (Farrell et al., 2000).

Consumers believe the celebrity has sufficient understanding and experience of the product she/he is endorsing and this is termed as (perceived) expertise. And trustworthiness is the quantum of confidence and honesty that people associate with the celebrity endorser (Dwivedi et al., 2015). 
Brands frequently pick celebrities from the product job or who are in the habit of using the product to impart the distinctive image of an expert or an opinion leader. Opinion leaders are believed to have the ability to influence opinions or beliefs of others; they also liaise between brands and their consumers. To sound credible, brands ought to choose effective opinion leaders (Hoyer et al., $2018)$.

However, Iniesta-Alemán (2019) point to tennis player Rafa Nadal as an example of an endorser whose lack of expertise in recommending a financial services provider, namely, Sabadell, failed the credibility test with consumers. The results found consumers failed to view a sportsman as having the expertise to be able to recommend a financial company compared to his hugely successful endorsement of sports as for example Nike. Munnukka et al (2016) sounds a cautionary note saying that consumers are going to draw the inference, based on a celebrity endorser's occupation and likely use of the product, that a certain celebrity is perhaps not going to be fully experienced in the products she/he is endorsing.

As a result, brands have to factor in their long-term aims and interests when choosing a celebrity for their product in order for consumers to deem the celebrity as credible and feel confident about the messaging that reaches them.

Sääksjärvi et al. (2016) opines that the attractiveness of a celebrity endorser is important in terms of exercising a positive influence. Research indicates that attractiveness determines a celebrity endorser is perceived credibility and quality. Attractiveness includes appealing physical appearance, facials, as well as body features, besides personal style. Endorsers who 
consumers considered as physically attractive were more successful in driving appreciable changes to consumers' purchase decisions than, say, by less attractive or "unattractive" comparisons (Spry et al., 2011).

Park and Lee (2014) say that attractiveness holds within its definition other factors such as personal characteristics (personality or social status for example).

A celebrity's admirers typically 'pick' characteristics of their object of admiration since it is their very aspiration to be like them.

In a world with ever-changing public interests, it is therefore critically necessary for marketers to identify the right kind of celebrity endorsers who people can find credible to provide an impetus to consumer buying process (Marshall \& Redmond, 2016).

The compatibility of the celebrity endorser with the brand (congruence) is another factor that influences the endorser's effectiveness (Silvera, 2004; Pradhan et al., 2016).

Congruence is essentially the perceived affinity between the brand, and the endorser. In commentaries about brand congruence, authors consider the logic and consistency between a celebrity endorser's characteristics and that of the products she/he endorses (Seno \& Lukas, 2007). As illustration of a successful celebrity endorsement, we can use the example of the actor George Clooney who was endorsing Omega's luxury watch collection. Backed by Clooney's physical attraction, Omega was able to make people believe that the celebrity was ideal, so celebrity brand congruence is important. 
Halonen-Knight and Hurmerinta (2010) feel a celebrity-brand mismatch might turn off people from buying the endorsed product. However small degree of incongruence in celebrity endorsement might stimulate buying behaviour. Compared to ads with a high degree of such congruence, those with little to moderate incongruence might actually end up generating more attention for the ad (Lee \& Thorson, 2008).

It is still not clear whether brands intentionally choose a celebrity to create incongruence and generate any interest thereof (Lee \& Thorson, 2008). Also, there is very little research regarding consumers preferring endorsement by a matching celebrity. Given this scenario, it is necessary to identify brands that might benefit from congruent endorsement and others that might stand to conversely benefit from incongruent endorsement (Halonen Knight et al., 2010)

Research models such as the "meaning transfer model" have drawn the conclusion that a transfer of associations occurs between the celebrity endorser and the endorsed product (Lea-Greenwood, 2012). These include the reputation and associated attributes the celebrity endorser has obtained externally from her/his film roles or in publicised personal life; all of these associations transfer to the endorsed brand and product (Halonen-Knight \& Humerinta, 2010).

The final stage of the model consists of a transfer of characteristics from the celebrity and the brand to the consumer through consumption, gifting or other possession of the brand (Darin et al., 2009). This model is particularly significant in that it tries to ascertain whether or not consumers believe the desired 
characteristics of the endorser and brand got transferred to them and, in addition, attempts to ascertain if the celebrity indirectly influenced them or not (Jain \& Roy, 2016; Halonen-Knight \& Humerinta, 2010).

Nevertheless, Jain and Roy (2016) also point to some negative connotation of the "transfer" process. Consumer studies indicate negative connections with the celebrity were more likely to be transferred to the brand than positive ones. What's more, negative associations with a brand can damage their brand image and reputation (Hood, 2012). Celebrities embroiled in sensational scandals can act as a drag on the effectiveness of their endorsements (White et al., 2007). As an example have reaction of Dior with Sharon Stone. On May 12 of 2008 over 69,000 people lost their lives when a massive earthquake hit southwest China. Sharon Stone took the news as an opportunity to get political, suggesting that the earthquake was "karma" because of Beijing's treatment of Tibet. Stone later apologized, but the backlash against the actress led luxury brand Christian Dior to cancel Stone's endorse contract (Xiao \& Li, 2012)

There is not research that prove if a negative event, such as a scandal, would have a direct influence on the "meaning transfer model," especially on the final phase of transference from brand to consumer. Even if we were to admit the possibility of such transfer, it is still not clear if negative associations are transferred to the same degree as positive associations or if consumers would still want to buy a brand endorsed by a tainted celebrity (Jain \& Roy, $2016)$. 
In sum, celebrity endorsement serves as a potent marketing tool wherever end users think the endorser is credible with regard to her/his expert skills, trustworthiness, and attractiveness. In this regard, it is important to develop an in-depth understanding of key concepts around consumer behaviour associated with the purchase of celebrity-endorsed products in order to reach the inference that celebrity endorsement influences such buying. (Wallace et al., $2014)$. 


\subsection{SOCIAL MEDIA AND CELEBRITY ENDORSEMENT}

Maturing of technology and rise to prominence of social media in particular have played a key role in redefining 'celebrity'. Celebrities increasingly connect with consumers/followers on Facebook, Instagram, Twitter and Snapchat, giving them a sneakpeak of their personal space, including of the products they use (Turner, 2014). A study of online celebrity presence by Kowalczyk and Pounders (2016), reveals that consumers felt motivated to buy products that celebrities endorsed via their social platforms, either implicitly or explicitly. People got the feeling of being able to connect with celebrities on a personal level and felt product recommendations they made were authentic.

However, participants in the above study were younger females, and other similar studies have also invariably centred on the same public. The UK boasts around 7 million female users on Facebook aged 40-60, as per Statisa (2019). This large populace on the social networking site certainly evokes keen interest and represents a compelling business opportunity to research how and to what extent this group is influenced by online celebrity endorsements (BrandFinance, 2019). 


\subsection{COSMETICS CONSUMER BEHAVIOUR}

Consumer behaviour may be defined as the series of actions, starting with the consumer's awareness of a brand, her/his response to information flowing from the brand about its products, as well as how she/he processes such information and makes it a baseline for making buying decisions (Boon-Long \& Wongsurawat, 2015). Solomon et al. (2006) offers another definition and explain the consumer behaviour consist in studding the process involve when individuals purchase, use or dispose of products, services, ideas or experiences in order to satisfy needs and desires. Kotler and Keller (2011), in their definition change the needs and desires of Solomon for needs and wants as Enis (1974).

Kumar (2010) refers to the consume of goods and services for personal consumption. Another valuable argument is provided by Egen (2007) regarding understanding consumer behaviour. According to him, awareness of consumer behaviour is a positive contribution to the country's economic state.

Recent research in luxury cosmetic industry has pivoted around brand loyalty, factors that influence buyer behaviour, and products favoured by different demographics. The next section will describe the nature, scope, and meaning of the marketing theory of a consumer's "self-concept" that is used to study how consumers are influenced by brands and what exactly influences them.

With the advent of social media, brands are well-placed to deliver bespoke messages to their target audiences. Besides, they 
can also keep a closet tab on online buying trends and behaviour. (Neti, 2011). This literature examines UK's market for female cosmetics, a fairly large one, and gives some thought to the demographics, market shifts, and factors influencing purchase decisions. In Europe and USA, the cosmetic market is expected to grow extensively in the next 5 years, especially in Spain and France (Apaolaza \&Harmann, 2007)

British women are less inclined to buy beauty products online as compared to shopping offline at beauty counters. This is a key insight for brands since footfalls in stores means they must engage customers with highly persuasive in-store ads (Mintel, 2019). Female consumers aged 16 and above, when they run out of cosmetics stocks, are more likely to buy the same brand to replenish the stock rather than try a new brand. Also, product preferences vary with age groups. Lipsticks are most popular with women aged 65 and above; The biggest buyers of eye-shadow pallets are 16-24year-olds since this is the stage of life when females feel the need for colour the most and show an urge to try out new shades and dazzling colours (Mintel, 2019).

Another of Mintel's (2019) findings was that women in the 40 60 age group like to spruce up their appearance much like younger women. More than a third of women in this demographic were fond of experimenting with new cosmetic brands while a marginally higher fraction of women in fact felt it is important to dabble in different brands in accordance with their bodily changes. However, it is still not amply clear whether this cosmetic take up by women helps in boosting their ideal-self or in achieving a sense of harmony with their actual-self (Nasir et al.,2016). 
The self-concept comprises a whole bunch of attributes that consumers assign to themselves. The self-concept takes its life from the consumer's self-esteem, their estimation of their overall competences, and how they think they appear to others around them (Matzler et al., 2015). The last factor, in fact, contributes a lion share to a person's self-concept. After all, consumers gain an understanding of their self-concept while involving with other individuals and their habitat in general (Goldsmith et al., 1999). The self-concept carries a lot of significance for brands because past studies have drawn attention to its preeminent role in influencing market take up (Goldsmith et al., 1999).

Soneji et al (2015) have performed further research on the self-concept, with emphasis on the Self-concept Clarity (SCC) model, which helps ascertain whether or not an individual's selfconcept has been defined confidently and consistently, and exhibits a certain stability. This model postulates that higher the SCC score, the more clarity a consumer will have about who she/he is. Conversely, consumers who score low on SCC could be expected to lack that clarity about who they are and lack the belief in themselves. More importantly, such individuals look to informed and credible external sources (e.g., celebrities) for guidance and counsel. Brands can turn this to good advantage provided they are sufficiently aware and have enough understanding of the selfconcept (Soneji et al., 2015).

Onkvisit and Shaw (1987) have historically defined the selfconcept along four key dimensions (namely, real self, self-image, ideal-self, and looking-glass-self) in their attempt to decode the 
consumer's self-image and its influence on purchasing decisions. However, more recent studies have narrowed it down to two dimensions: actual-self and ideal-self. The actual-self is how individuals actually see themselves; ideal-self is how persons would like to see themselves and be seen and interpreted by others (Peters et al., 2011).

Castro and Marquez (2017) posit that brands must target the type of self-concept (ideal or actual) based on the nature of their product. For instance, offerings belonging in the 'communicating product' category are openly consumed in public and have the objective of boosting the user's self-esteem. Since augmented selfesteem is the ideal image of her/his self that the user wants to convey to others, the brand in question should target the user's ideal-self as different from the actual-self.

The self-concept has a bearing on how consumers perceive and interact with celebrity endorsement, so it is imperative that brands carefully select a celebrity endorser who closely corresponds to the target user's self-concept (Goldsmith et al., 2012). Onkvisit and Shaw (1987) think a brand's awareness of the self-concept will enable it to tailor effective celebrity-endorsed marketing strategies that are spot-on.

The younger crop of consumers is still in the process of building out their ideal-self; therefore, it is only natural that they look to celebrities for inspiration in matters like style, values, and attributes. They are more likely to buy an offering that was endorsed by a celebrity who they thought was an inspiration. When it comes to the mature market, there is scant research about the effectiveness and influence of celebrity endorsers. It remains a 
matter of speculation whether a mature market does indeed turn for inspiration to celebrities who potentially match their ideal or actual-selves (Boon \& Lonmore, 2001).

By purchasing products backed by celebrities, consumers probably stand to acquire the desirable associations represented by the celebrity and augment their own ideal-self-image, a viewpoint underscored by Choi and Rifon (2012). They further hypothesise that consumers will develop a positive attitude toward a brand once they believe there is a great deal of similarity between the celebrity concerned and their own ideal-self

For the same reason, people typically relate better to an endorser who they consider 'normal-looking,' with a greater perceived similarity with themselves, compared to another celebrity who comes across as highly attractive. This could also be a case of brands effectively targeting consumers' actual self and, in the process, allowing the truth to sink in that matching or attempting to match the looks of the celebrity featured in the ad is an unrealistic and meritless pursuit (Tantiseneepong et al., 2012).

Choi and Rifon (2012) often talk about the selfimage/product-image congruence model that lays emphasis on how congruence between consumers' ideal-self and the product influences affects their orientation towards both the ad and the brand. Consumers develop positive belief sets about the brand where it is congruent with their self-image. A fit between a brand image and the consumer's actual self is termed 'self-congruity' while a fit between a brand image and the consumer's ideal self goes by the name 'ideal-congruity'. 


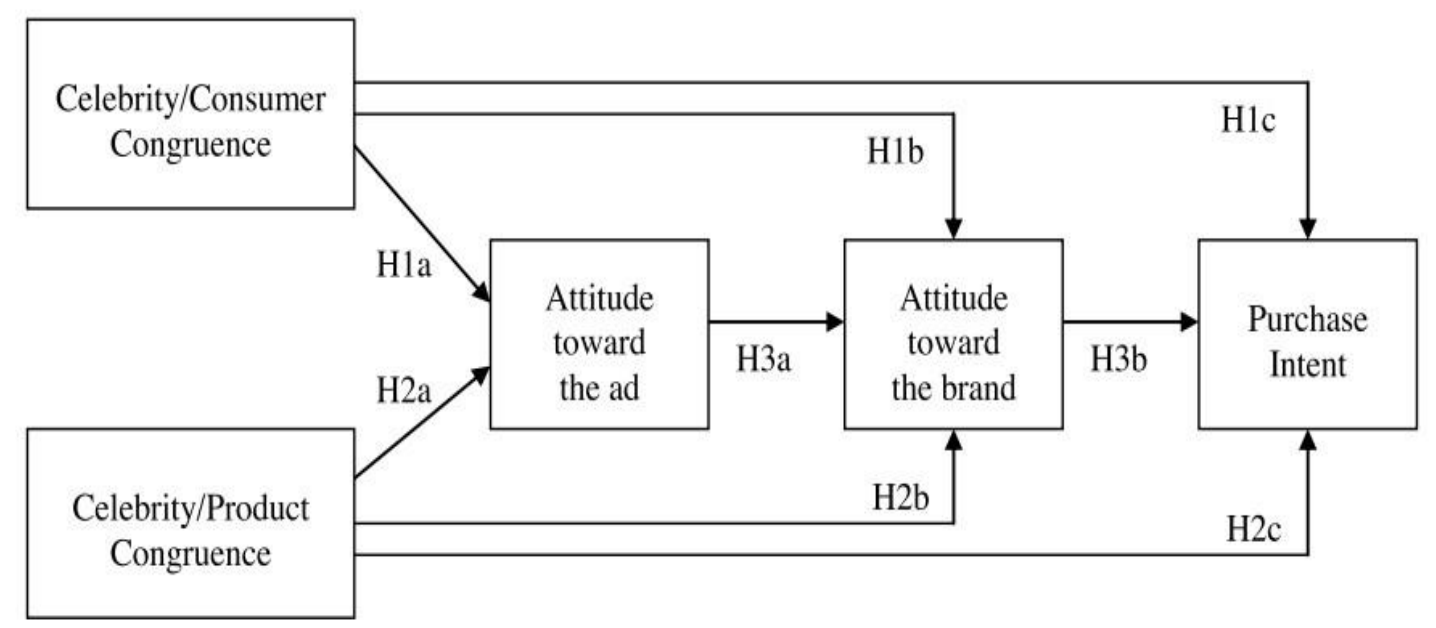

Image 1: Self-image congruence model by Chio \& Rifon, 2012.

The model represented in Image 1 explain that a high congruence level between a celebrity endorser's image and a consumer's ideal-self will result in more favourable attitudes towards the ad and the brand as well as a greater purchase intention in relation to the brand (Chio and Rifon, 2012).

The customer's positive feeling towards the ad, by extension, results in a positive connection with the featured brand, and this attitude, in turn, directly links to the customer's buying decisions. This model, however, has limited research underpinning it; besides, it may not be in a position to account for the sentiments of consumers belonging to all age groups (Hood, 2012). Nevertheless, this model can tell if the congruence between the celebrity and consumers' ideal self can influence their outlook on the brand under consideration. Besides, this model could potentially help determine whether negative vibes given off by the consumer to the celebrity can give rise to negative attitudes towards the brand, which could come in the way of the purchase intention (Jain \& Roy, 2016). 
Choi and Rifon (2012) explained some strains in consumer behaviour that seem to indicate that people settle for brands that represent a right-fit for or correspond to their ideal-self, a relationship referred to as consumer-product congruence. So far as the meaning-transfer model is concerned, people subconsciously think that the positive qualities ingrained in the product and brand will move to them, and, by so doing, further improve their image of their ideal self (Lea-Greenwood, 2012). Along the same lines, Choi and Rifon (2012) presume that buyers consume, purchase, and repurchase products from brands that they have reason to believe will augment their ideal-self and correspond closely with their ideal self. Most research finds that brands tend to derive the most value from targeting people' actual-self or ideal-self (Solomon et al., 2006).

It has been suggested that wherever a consumer's ideal-self conforms to a brand's personality (human characteristics that are often extended to a brand), it drives up the consumer's satisfaction levels. Hence, it is crucial for brands to engage their target consumers effectively and intelligently via celebrity endorsement (Kumar, 2010). Businesses must put the finger on their consumer's understanding of her/his actual and ideal-self and define which of these selves will sit well with their ad. The marketing communication should not only be in synch with consumers' aspirations around how they want to appear on the outside but also match their values and attributes (Seno \& Lukas, 2007). 


\subsection{CONCLUSION}

While credibility represents an important arsenal in the endorser's armour, this credibility comprised different aspects, and these were valued differently by various demographics. Research has also identified a clear match or chemistry between brand and endorser on one hand, and between endorser and consumer on the other. This means it is crucially important to pick the right-fit celebrity capable of nurturing in consumer's favourable attitudes towards the brand. There are also interesting insights on how various nuances of how consumers make decisions about luxury cosmetics purchase can also affect how celebrities influence them. All the same, there is no data on the various influences on the mature female market, which makes a case for research on celebrity endorsement in the luxury cosmetics sector and market for mature females. 
AIM AND OBJECTIVES 
This thesis essentially aims to examine the way buying behaviour of mature female consumers aged 40 to 60 in the matter of luxury cosmetics is influenced by celebrity endorsement. The objectives are to:

- Examine the awareness or recognition level of mature female consumers with respect to celebrity endorsement campaigns by luxury cosmetic brands.

- Identify the features that they deem most credible in a celebrity endorser.

- Examine how mature female consumers perceive their own ideal self and whether the luxury cosmetic brands they buy are in synch with this ideal self.

- Analyse, from the standpoint of mature female consumers, whether luxury cosmetic brands are successfully choosing appropriate celebrities to endorse their brand.

Provide actionable recommendations, which will help stimulate further research to possibly improve the potential of celebrity endorsement as an efficient marketing tool for luxury cosmetic brands now and in the future. 
METHODOLOGY 


\subsection{INTRODUCTION}

This chapter aims to present a methodological framework that will enable a meaningful investigation of the aims and objectives underlying this research. Each section is dedicated to a critical inquiry and rationalisation of the research choices made by the study. The research approach and the data collection will be explained and the chapter concludes with a mention of its limitations and conclusions. 
In order that the research is effective and meaningful, it is important to understand what kind of data needs to be collected to fulfil the research objectives (Wilson, 2014). The following research rationale gives an indication of primary and secondary data and explain which of these is advantageous to the study.

Primary data is typically gathered $r$ using surveys, interviews, and other collection methods keeping in mind the specific requirements of the research topic. Basically, primary research is independent of any pre-existing data collected by a previous researcher (Sreejesh et al., 2014). Primary data has historically been expensive from a cost and time perspective but the arrival of social media and other relatively newer crop of technologies has enabled easy sharing of, say, questionnaires, with a large sample of consumers without having to worry about cost (Zikmund, 2009). At the time of this research, there is no pre-existing secondary data that considers the awareness level of mature female consumers in the cosmetics market about their ideal-self and further correlates the same with celebrity endorsement. Besides, a major chunk of contemporary research is centred on the awareness of relatively younger female consumers about celebrity endorsement and the attributes of celebrity endorsers that they consider important. Therefore, collecting primary data, which involves gathering fresh responses from mature female consumers, a segment not sampled by any past study, will precisely address the aims of this current research (Bryman \& Bell, 2011). 
Regarding the research approach on which the methodology of this study is predicated, alternative approaches are critically considerate in order to establish the most relevant for this particular research. Positivism and interpretivism are popular epistemological research paradigms. Epistemology is the nature of knowledge the researcher has about the external environment as well as her/his outlook on the external environment (Saunders et al., 2009).

A paradigm exerts a certain influence on the research and the same is chosen as basis when conducting a study based on the outlook and attitude of the researcher as well as her/his conviction of how data should be collected, examined, and leveraged (Bryman \& Bell, 2011).

Positivism concerns itself only with the application of science to authenticate a certain social phenomenon. It is essentially a fundamental study that applies existing theory to the analysis of a situation with a view to validate it and, in the course of it, the researcher remains objective (Saunders et al., 2009).

Interpretivism is basically the belief that social features of the world of business are too complex to be validated through the application of natural sciences. By extension, in order to understand social phenomena, the researcher must participate in the social environment in which it takes place. This philosophy calls on the researcher to be subjective and holds the belief that individuals experience phenomena in different ways (Wilson, 2014).

The following research seeks to follow the positivist route. The philosophical paradigm of positivism sits well with this research 
because of the application of existing celebrity endorsement theories. Wilson (2014) opines that positivism is centred around whether or not the social word can be researched using natural science as a basis and regards as important the application of literature to the study of a social phenomenon. The interpretivists believe that every single participant has her/his individual experience that theory cannot generalize.

The positivists state that the researcher is the person who is being objective to the phenomenon under research. The researcher is objective about how celebrity endorsement impacts mature females; therefore, the research is independent of any preconception (Hugosson, 2014).

Identifying the research approach is the next logical step, and this could be either inductive or deductive. The key influence here is the positivist research philosophy (Wilson, 2014). In the inductive approach, the research is centred on collecting data and, based on its conclusions, evolving a theory. On the other hand, the focal point of a deductive approach is the relationship between theory and research, and, furthermore, application of theoretical frameworks to the research. It is considered an element of the positivist philosophical theory (Ghauri \& Gronhaug, 2005).

This study embraces the deductive approach since theoretical framework like the self-concept is put to use in this research to develop an understanding of how they affect the mature female user market. The other overarching reason why the deductive approach is best suited to this study is that it underscores the relationship between research and theory by drawing on preexisting literature on celebrity endorsement to realise the 
objectives. An inductive approach is ruled out since the study doesn't aim to develop a new theory around celebrity endorsement as a marketing strategy (Saunders et al., 2009).

The philosophy and approach underlying a research is responsible for shaping its design. Any study could choose to follow one of three research designs: exploratory, descriptive, and explanatory. (Burns \& Burns, 2008)

Exploratory study interrogates what is happening in the context of the research by employing inquisitive research methods and seeks to frame new theories and push the envelope of knowledge (Wilson, 2014).

Descriptive involves carrying out research around contemporary or past phenomena and employs various interview methods to collect data. (Gill \&Johnson, 2010).

Explanatory research concerns itself with uncovering relationships between different variables responsible for causing a certain phenomenon. In general, it endeavours to establish a causeand-effect relationship between a phenomenon and the reason that provoked it (Blumberg et al., 2014).

As seen in above, since an exploratory design works towards developing a new theory, it has little or no relevance to the current study whose intent and purpose is to relate contemporary writings on celebrity endorsement to the understanding by mature female consumers of celebrity endorsement as well as their own interpretation of their ideal selves. And because this study doesn't seek to contribute to any new theory by putting to use inquisitive 
research tools, exploratory design can be eliminated from its scope (Van Dick et al., 2008).

The study fundamentally aims to perform a systematic inquiry into how celebrity endorsement influences the purchasing choices of mature female consumers with a view to establish the facts of the case. Therefore, by adopting a descriptive approach, complete with structured interviews and questionnaires, the research can hope to gain an accurate and deep understanding of the characteristics they think are important in a celebrity endorser (Blumberg et al., 2014).

The celebrities chosen for the study are Monica Belucci, Liv Tyler and Carla Bruni, all three because they are well-known celebrities in the UK and who are within the age range corresponding to the study.

The Chanel, Dior and Givenchy brands were chosen because they are renowned luxury cosmetic brands well-known in UK for using celebrities in their marketing campaigns.

The campaigns were chosen at random since the type of campaign and the chosen media of dissemination were irrelevant for the type of questions that would be asked, since the questions are generic and the media do not influence the answers or the type of campaign chosen.

The dates of the campaigns chosen were random because they did not influence the study.

Below are the images used: 


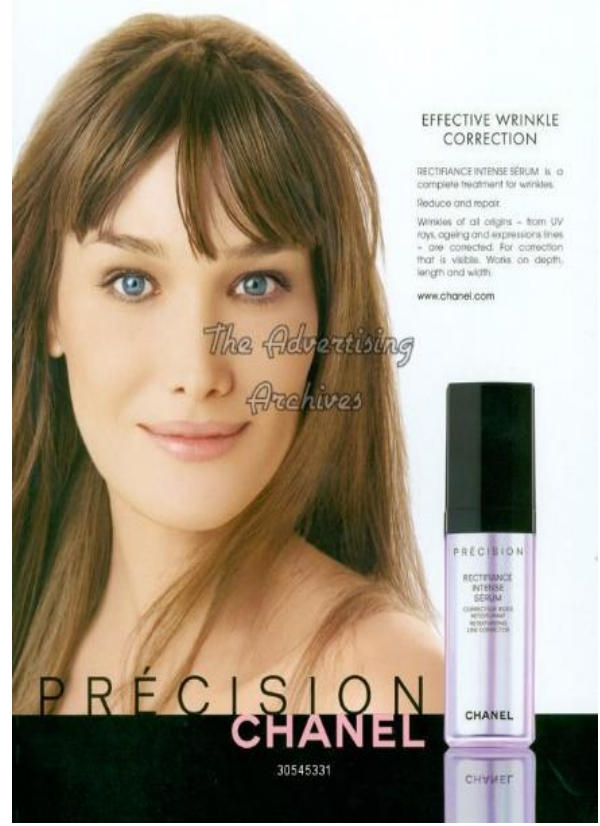

Note1. Adapted from The Advertising Archives [Picture], by The Advertising Archives, 2005, (https://www.advertisingarchives.co.uk/?service=asset\&action=show_zoom_window_popup\&language =en\&asset=41032\&location=grid\&asset_list=87519830,87519665,87519294,41032,17723,16119,10509 \&basket_item_id=).
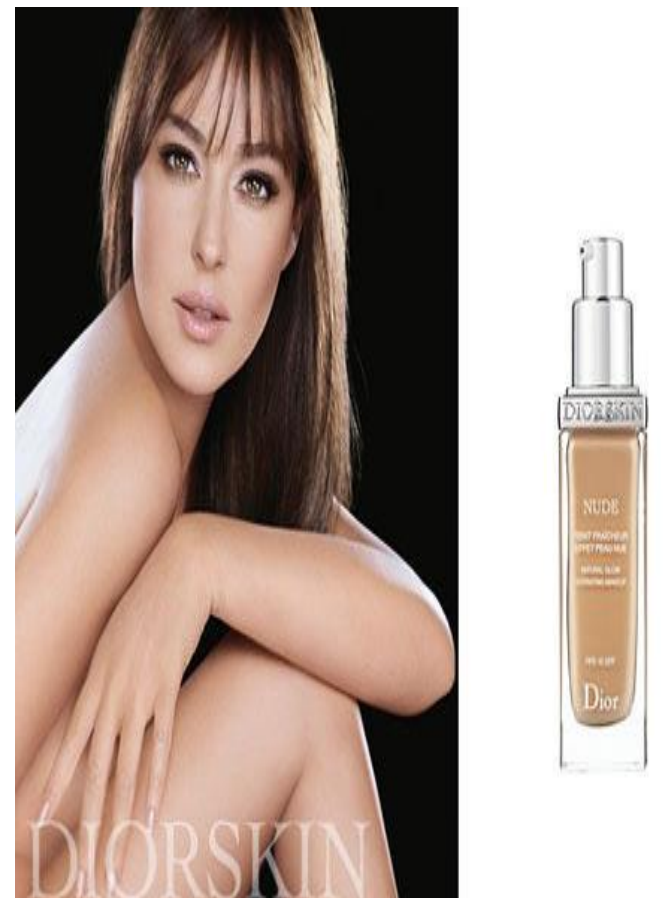

Note2. Adapted from New Foundation Makeup Products for Spring 2009 [Picture], by Genius Beauty Online Women's Magazine, 2009, (http://geniusbeauty.com/make-up/new-foundation-makeupproducts-for-spring-2009/). 


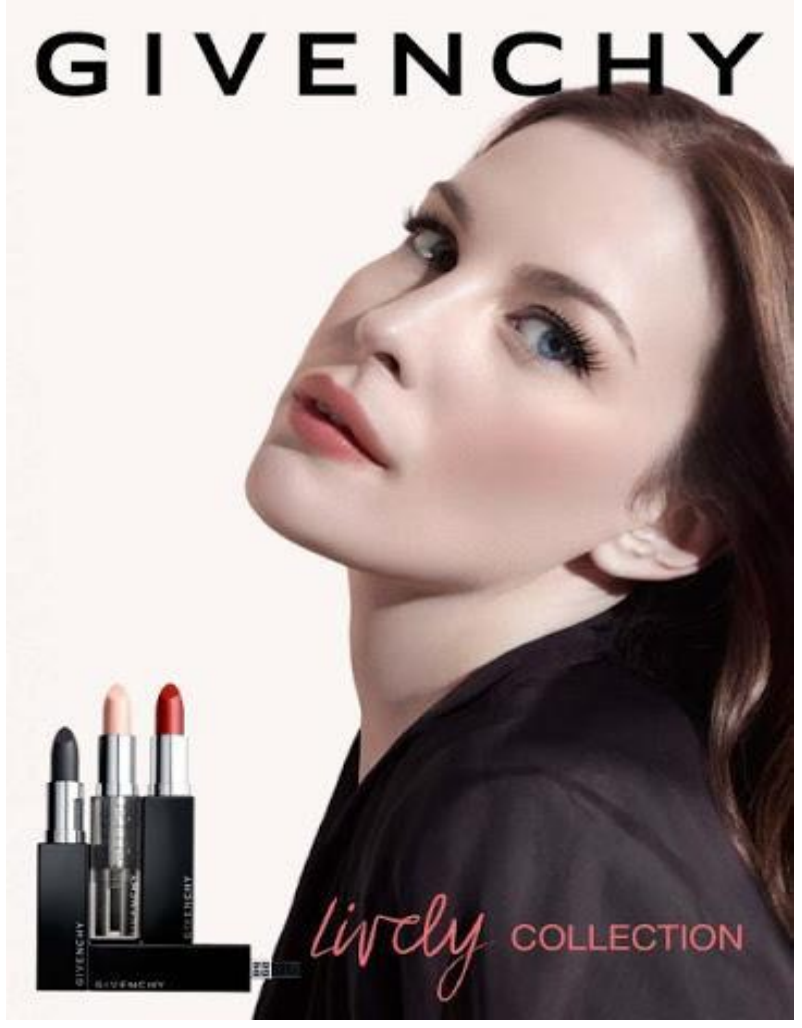

Note3. Adapted from Givenchy Beauty Lively Collection F/W 12 [Picture], by Modelsdotcom, 2012, Pinterest (https://www.pinterest.es/pin/541909767645923609/\#details?amp_client_id=ampfRvly3hPyILGAAUaePuUuA\&mweb_unauth_id=b432c0a6144f45d0bcbcff78d172fef5\&amp_url=https\%3 A\%2F\%2Fwww.pinterest.es\%2Famp\%2Fpin\%2F541909767645923609\%2F). 


\subsection{DATA COLLECTION}

Research will use the mixed-method strategy, which employs quantitative and qualitative methods for gathering primary data.

Quantitative research can be general when it comes to analysing the awareness level of consumers and the attributes of celebrity endorsers that consumers deem relevant. This means the researcher can use a large sample to take stock of any common themes in the data (Wilson, 2014).

This research is deductive, so it is worthwhile to get qualitative data as well, via interviews, and this will provide further granularity and detail to the questionnaire responses. Qualitative research imparts more depth, overall, when it comes to interrogating literature concepts unlike numerical data generated via quantitative tools that fail to bring out people's perspectives around their own ideal-self (Baxter, 2015).

Key data method used in quantitative data collection is the questionnaire (Zikmund, 2009). A questionnaire comprises of structured questions designed to realize the objectives outlined by a study. Postal and online questionnaire are some variants of this tool. Questionnaires help in obtaining information. Web-based questionnaires can be administered free of cost and in a timely manner to a large population. In this approach, respondents get enough time to answer the questions without feeling any undue pressure (Baxter, 2015). Sometimes, respondents interpret questions wrongly, leading to incorrect and invalid responses. A lot of care should go into framing structured questions needed to elicit 
the right responses and valid data. There is the possibility of the questionnaire being administered to the wrong persons or sample, and the result is inaccurate representation of the sample. Mailing out questionnaires can be a tedious and time-consuming exercise (Saunders et al., 2009)

This study aims to reach out to a large number of female consumers aged 40-60, so an online questionnaire is most appropriate. Also, as previously stated, the positivist theory and approach that typifies this research involves generalising within the study based on results gathered from a large sample.

Needless to say, sending and receiving individual postal questionnaires is a time-consuming and wasteful process while online questionnaires are faster to administer and process (Jankowicz, 2007).

This study also makes use of interviews as a data collection method to supplement data provided by online questionnaires as well as explore in depth the perspectives of mature female consumers on various literature concepts in celebrity endorsement.

As observed by Wilson (2014), face-to-face interviews have the advantage of letting the author talk at length with respondents and flesh out more details about the individual's attitudes and beliefs with respect to a subject, rather than banking simply on nonverbal communication. The researcher can ensure she/he is on the same page as the respondent by explaining the concept of celebrity endorsement in more detail before plunging into the interview (Sekaran \& Bougie, 2013). 
The online questionnaire must include questions that are well-structured and sufficiently open-ended while being specific enough to capture precise data that maps to the research objectives (Baxter, 2015).

Questionnaires typically include different types of questions (Baxter et al., 2015). The key features of each type of questions are: Open, Closed, Multiple choice, Likert scale and Rank order questions. (Wilson, 2014)

In the open questions, the respondents are free to provide any kind of response, be it detailed or lengthy. The close questions limit the answer of the respondents (e.g. Yes or No).

Multiple-choice questions force respondents to pick one or more answer from a set of predetermined answers. Liker scale questions are used to reckon the respondent's attitude toward a statement or question based on the option she/he has chosen such as 'Agree,' 'Disagree,' or 'neither Agree or Disagree and Rank order questions required to Rank options by order of preference.

For this study, closed questions with fixed responses are the most appropriate. Also multiple choice options and ranking scales are suitable.

The online questionnaire returns quantitative data; therefore, responses from the questionnaire needs be simple and easy to slice and dice. As mentioned above, if participants are allowed to answer however they please, the result could be lengthy and digressive answers that are going to be difficult to decode. (Bryman \& Bell, 2011). Since trustworthiness, attractiveness and expertise have 
been identified as the attributes that contribute to the endorser's credibility, it is only appropriate to let participants rank them in their order of priority and establish levels of importance. A ranking scale method is utilized to get a handle on which factors are the most valuable for consumers in the cosmetics market.

Closed questions have the advantage of returning succinct and simple responses and can be easily administered to a fairly large sample. According to Baxter et al., (2015), questions tend to attract participants' interest than, say, statements on a Likert scale; the latter often suffers from 'acquiescence bias,' which causes respondents to agree with or positively answer the questions posed. On the other hand, when faced with a 'Yes' or 'No' answers, respondents have to necessarily choose one and only one that connects with their specific scenario. In addition, open-ended questions are also included in this research to provide them with enough latitude to develop answers of their choice. When considering the awareness level of mature female consumers about celebrity endorsement in the luxury cosmetics market, they are encouraged to name celebrity endorsers they are aware of. This gives the researcher a sneak-peek into the kind of celebrities this market segment is more likely to recognize (Bloomberg et al., 2011).

In a structured interview, respondents are provided with identical questionnaires, which facilitates a comparative analysis of responses. By contrast, the unstructured interviews with opens up a field of questions, which are triggered by the interviewees' initial responses (Jankowicz, 2007).

So far as the current study is concerned, the interviews will have open-ended questions whose focus is on consumer behaviour 
and celebrity endorsement; however, there is no provision to allow interviewees to expand their initial answers any further. But the interviews certainly provide a window for the author to show any concept that the interviewee is not aware of. Terms like 'selfconcept", or "congruence" are explained to dispel any ambiguity in the respondent's mind as would result in unclear answers. The interviews will show images to interviewees and then proceed to ask them to identify attributes they would typically relate to the celebrity and brands they endorse. They are also quizzed about whether they believe the celebrity is indeed a right-fit for the brand she is endorsing (Bloomberg et al., 2011). 
Legal framework:

The General Data Protection Regulation (EU) 2016/679 (GDPR) is a regulation in EU law on data protection and privacy in the European Union (EU) and the European Economic Area (EEA).

The GDPR's primary aim is to give control to individuals over their personal data and to simplify the regulatory environment for international business by unifying the regulation within the EU. (Presidency of CEU, 2015)

Business processes that handle personal data must be designed and built with consideration of the principles and provide safeguards to protect data (for example, using pseudonymization or full anonymization where appropriate). Data controllers must design information systems with privacy in mind. For instance, using the highest-possible privacy settings by default, so that the datasets are not publicly available by default and cannot be used to identify a subject. No personal data may be processed unless this processing is done under one of the six lawful bases specified by the regulation (consent, contract, public task, vital interest, legitimate interest or legal requirement). When the processing is based on consent the data subject has the right to revoke it at any time. (Lucarini, 2020)

Data controllers must clearly disclose any data collection, declare the lawful basis and purpose for data processing, and state how long data is being retained and if it is being shared with any third parties or outside of the EEA. Firms have the obligation to 
protect data of employees and consumers to the degree where only the necessary data is extracted with minimum interference with data privacy from employees, consumers, or third parties. Data subjects have the right to request a portable copy of the data collected by a controller in a common format, and the right to have their data erased under certain circumstances. (Lucarini, 2020)

As the GDPR is a regulation, not a directive, it is directly binding and applicable, but does provide flexibility for certain aspects of the regulation to be adjusted by individual member states. For this reason we must to look at UK law to comply with it. (Lucarini, 2020)

The Data Protection Act 2018 is a United Kingdom Act of Parliament which updates data protection laws in the UK. It is a national law which complements the European Union's General Data Protection Regulation (GDPR) and replaces the Data Protection Act 1998. (UK Public General Acts, 2018)

Everyone responsible for using personal data has to follow strict rules called 'data protection principles'. They must make sure the information is:

- used fairly, lawfully and transparently

- $\quad$ used for specified, explicit purposes

- used in a way that is adequate, relevant and limited to only what is necessary

- accurate and, where necessary, kept up to date

- kept for no longer than is necessary

- handled in a way that ensures appropriate security, including protection against unlawful or unauthorised processing, access, loss, destruction or damage. 
There is stronger legal protection for more sensitive information, such as:

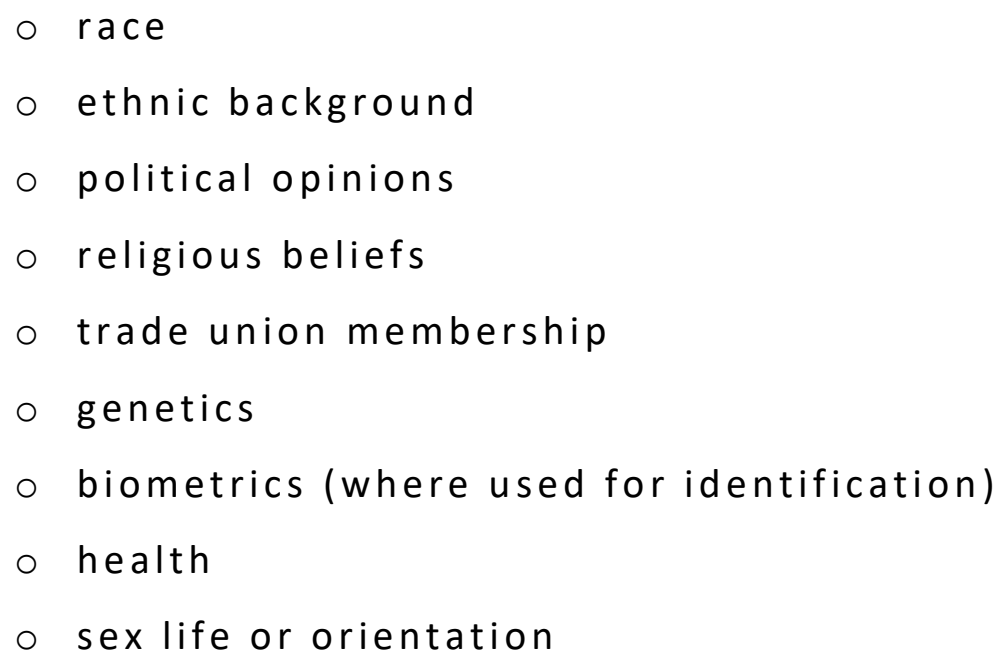

There are separate safeguards for personal data relating to criminal convictions and offences.

Under the Data Protection Act 2018, you have the right to find out what information the government and other organisations store about you. These include the right to:

- be informed about how your data is being used

- access personal data

- have incorrect data updated

- have data erased

- stop or restrict the processing of your data

- data portability (allowing you to get and reuse your data for different services)

- object to how your data is processed in certain circumstances

You also have rights when an organisation is using your personal data for: automated decision-making processes (without 
human involvement) and profiling, for example to predict your behaviour or interests. (Government UK, 2018)

Once we have discussed the legal framework, we are going to define the data protection policy carried out in the thesis.

For one hand, the online survey is anonymous. No personal data was requested. In addition, prior to its completion, informed consent was requested in which they accepted the treatment and administration of the answers for educational purposes only for the completion of said doctoral thesis, they were informed of where and the time during which the data would be saved. And they were also warned that the data would not appear raw in the thesis but only descriptive of the total of the answers.

On the other hand, the interviews were anonymized by assigning random numbers from 1 to 10 . At no time were questions asked about personal data that could lead to the identification of the interviewees. Prior to conducting the interviews, they were given to sign an informed consent in which they accepted the treatment and administration of the responses for educational purposes only for the completion of said doctoral thesis, they were informed of where and the time during which they were going the data to be saved and they were also warned that the data would not appear raw in the thesis but only excerpts from the interviews.

It should be noted that the online survey was conducted through the SurveyMonkey platform. SurveyMonkey complies with relevant laws and regulations, be it the recent European Union Data Protection Regulation (GDPR) or HIPAA requirements for the collection and handling of protected health information. 
Further:

-Apply a vulnerability management program, a continuous review is performed and corrective measures are applied to network equipment, workstations, servers and applications.

- Have carefully chosen hosting providers that adhere to the best technical and security practices

- Keep your team informed and engaged: Your entire group receives ongoing training on security and customer privacy in order to maintain your high standards. (SurveyMonkey) 
The focus of the current research is on mature female luxury cosmetic consumers in the 40-60 demographic. As it is impossible to collate data from the entire universe of the females in the age of the study, a representative sample that sums up the population in a nutshell would have to be considered.

This research makes use of non-probability sampling to understand the view of point of mature female luxury consumers aged 40-60. There are multiple types of non-probability sampling techniques (Easterby-Smith et al., 2012).

Types of sampling by Jankowicz (2007) and Easterby-Smith et al. (2012):

\begin{tabular}{|l|l|}
\hline Snowball Sampling & $\begin{array}{l}\text { Select participants that meet the criteria for } \\
\text { participation, and then they invite other } \\
\text { participants who meet the identical criteria } \\
\text { to participate. }\end{array}$ \\
\hline Sampling & $\begin{array}{l}\text { Selects participants because they are } \\
\text { available and accessible. } \\
\text { This is practical and cost-effective, as the } \\
\text { involvement of people you know is usually } \\
\text { easy to get. } \\
\text { Quota Sampling }\end{array}$ \\
$\begin{array}{l}\text { Collecting representative data from sub- } \\
\text { groups. These application guarantees that } \\
\text { sample people represents } \\
\text { characteristics of the population chosen by } \\
\text { the author. } \\
\text { Table 1: Types of sampling by Jankowicz(2007) and Easterby-Smith et al. }\end{array}$ \\
\hline
\end{tabular}

(2012) 
Snowball sampling technique comes across as the most effective method for the current study based on the evaluation of competing sampling methods. Snowball sampling carries the clear advantage that it can be conveniently shared by the researcher online with female luxury consumers aged 40-60 within her/his family and friends circle as opposed to convenience sampling in which just about anyone who is available on hand can readily participate. Furthermore, with the snowball approach, the researcher's family and friends can share the same questionnaire with their online friends who answer the same criteria and get them to participate. In effect, 'snowballing' the sample size with little effort. Quota sampling was ruled out as the study doesn't call for representing the entire population, given the unique criteria of the samples (Ticehurst \& Veal, 2005).

One hundred online surveys shared via Facebook and 10 structured interviews were carried out. The population for the survey was UK female residents between 40 and 60 years old, and the people interviewed were mature females from Glasgow due to what was convenient for the researcher. The period of data collection was from $1^{\text {st }}$ May 2019 to $31^{\text {th }}$ July 2019. 


\subsection{DATA ANALYSIS}

The results are then collated and analysed in a very effective way (Burns \& Burns, 2008). Microsoft Excel is preferred over SPSS, considering that the latter is relatively complex and this research has limited time on hand. The research design in this case is descriptive, which means there is hardly any need to perform statistical tests for the quantitative data here. Survey Monkey was used to export the 100 responses and appropriate graphs plotted based on the data therein to highlight the themes involved (Wilson, $2014)$.

Transcriptions were made of all interviews, and this made it easier for the researcher delineate any raw patterns or themes therein. The interviews were organised by themes alongside the corresponding objectives: awareness, characteristics and the selfconcept. This laid a framework for the subsequent findings and analysis section. 
Time is a key constraint in this study due in large to the 'snowball effect'. Obviously, more time will be required for sharing the online questionnaire and, there is going to be a corresponding delay in receiving results. To keep the delay down to the minimum possible, a deadline is clearly called out within the opening statement to serve as a wakeup call for respondents to fill in the questionnaire and share by the due date (Zikmund, 2010).

As participants may have doubts regarding the questionnaires, the researcher has included the researcher's name and contact, so participants could get back for clarification where required (Baxter et al., 2015).

Using Survey Monkey, the researcher created, administered, and collated 100 questionnaire responses. As it is generally known, more than 100 responses are required in order to have a strong generalization around a certain population as a whole.

One hundred responses can also be seen as a limitation, logically, a mayor number of answers will have improved the result (Surveymonkey.com, 2019). 


\subsection{CONCLUSION}

To conclude we can explain that the Research Philosophy is Epistemological and Positivist, the Research Approach is Deductive, and the Research Design is Descriptive. The Research Strategy in order to investigate how celebrity endorsement influences mature female luxury consumers use Qualitative and Quantitative data tools. The data collection will be carried out throw Online Questionnaire \& Structured Interviews. And finally, the Data Analysis Techniques use Excel and Thematic Analysis. The findings help us to provide recommendations to improve the efficacy of celebrity endorsement as a marketing tool in the luxury cosmetics segment. The confidentiality of the data was respected and the anonymity of the participants was guaranteed.

This image shows the methodology:

\begin{tabular}{|l|l|}
\hline Research Philosophy & Epistemological - Positivist \\
\hline Research Approach & Deductive \\
\hline Research Design & Descriptive \\
\hline Research Strategy & Quantitative and Qualitative \\
\hline Data Collection & Online Questionnaire \& Structured \\
Data Analysis & Excel and Thematic Analysis \\
Techniques & \\
\hline
\end{tabular}


FINDINGS \& DISCUSSION 


\section{CHAPTER 5 - FINDINGS}

5.1 INTRODUCTION

This chapter presents an analysis of the inputs generated from the online questionnaire shared via Facebook as well as from structured interviews comprising standardised questions. The models used for the interviews and the online questionnaires appear in the appendix A and B. 
Some questions of the online questionnaire and the interview study the recognition level of female luxury cosmetic consumers with regard to celebrity endorsement.

All the people participant in the study knew what celebrity endorsement mean, and 90 percent of them manage to recognize celebrities who endorse various cosmetic products. Claudia Schiffer, Carla Bruni, and Penelope Cruz, endorsers of Chanel, were celebrities recognised very easily by interviewees. Every single interviewee had watched celebrity endorsed products advertised on television, and a majority of them were mindful of their presence in stores.

The following question of the interview quizzed interviewees as to whether their purchase of any product had been influenced by celebrity endorsers, and $90 \%$ of respondents answered in the negative. Knoll and Matthes' (2016) opine that implicit advertising, wherein a celebrity subtly suggests that they use a certain brand, is capable of persuading a consumer to use the product. Interviewee \#1 and \#7 responded that they would be willing to try a celebritybacked product:

Interviewee \#1: "I'd be very keen to find out if they [celebrity endorsers] really use the product and aren't just doing it just for the sake of money."

Interviewee \#7: “I don't think I am going to be excited though. If I saw someone [a celebrity] I liked or admired I might try out the 
product they are using. But I'd like to believe that they indeed use it."

Interviewee \#1 and \#7 said they would like to presume that celebrity endorsers are also users of the product in question, an indication that implicit celebrity endorsement was more effective vis-a-vis explicit endorsement. In addition, six out of seven respondents who said celebrity endorsement was influential in persuading them to buy a certain brand seemed to believe that the celebrity used the luxury brand and derived the benefits endorsed by her/him. This is very much in line with Seno and Lukas (2007) view that implicit endorsement is more effective.

The questionnaire also asked participants to rank factors (price, packaging, quality and celebrity endorser) they thought were critical to cosmetics buying on a scale of 1 to 4 , " 1 " being most important and "4" being least important. As shown in the Image 2, a majority of female consumers aged 40-60 ranked quality as the most important factor, and celebrity endorsers the least important, in their choice of a luxury cosmetic brand. 
Most important factors when purchasing luxury cosmetics

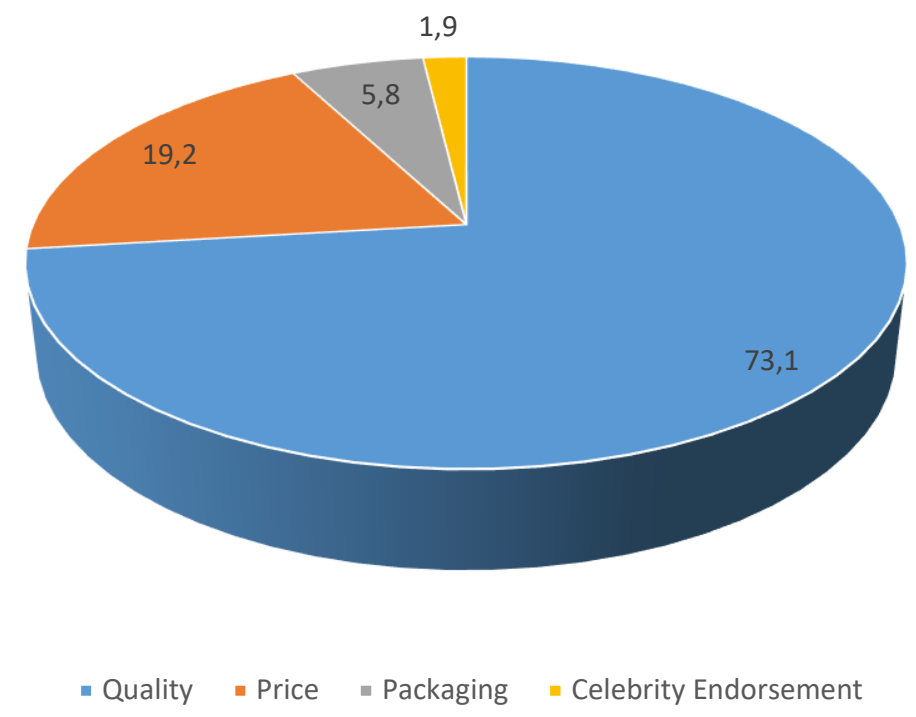

Image 2: Most important factors when purchasing luxury cosmetics

Hence, it can be inferred that celebrity endorsement is not significantly important for this cosmetics segment even where they know who is endorsing a certain product.

The following figures show the number of respondents to the online questionnaire and the extent to which they have ever been influenced by celebrity endorsers on social media sites: 


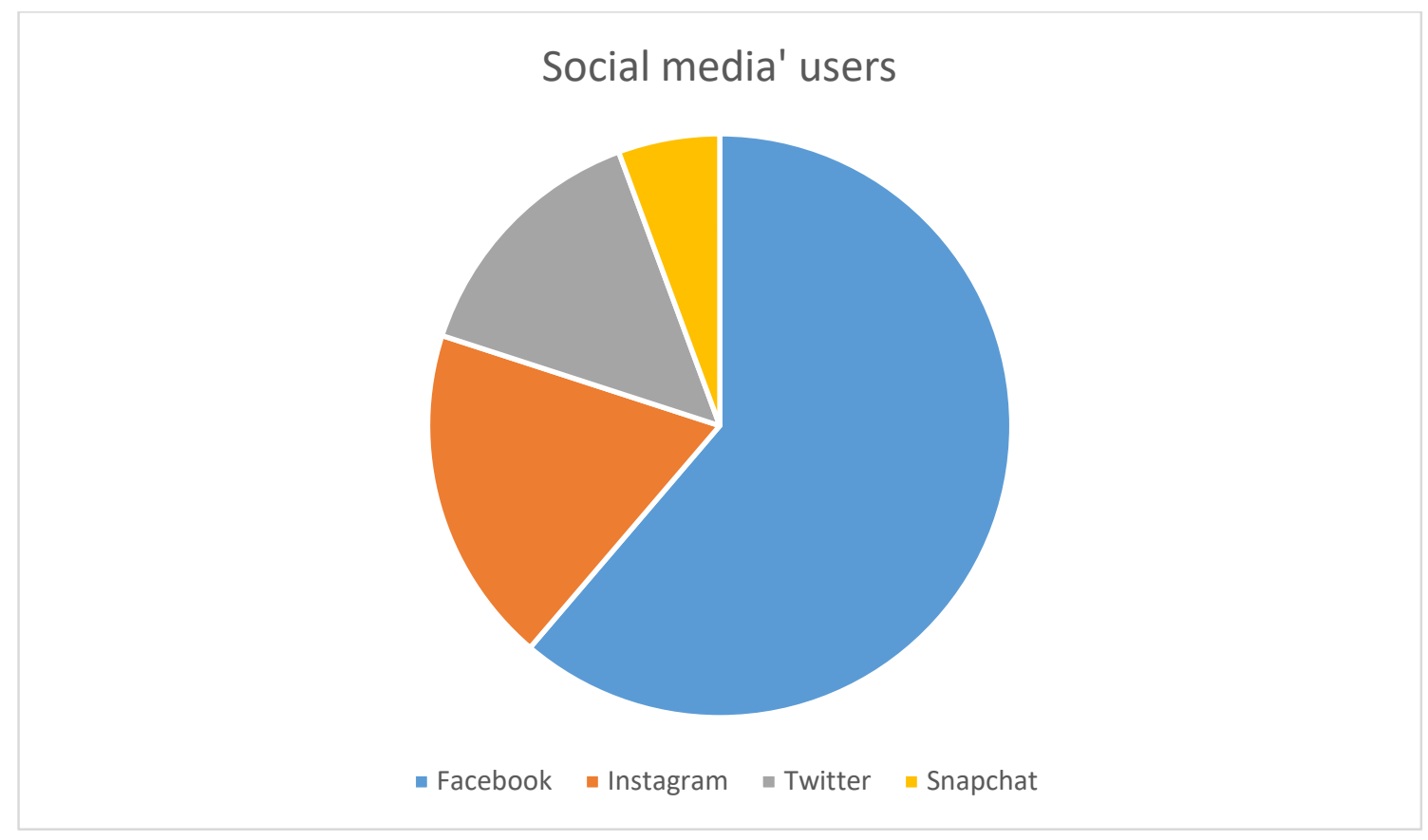

Image 3: Social media' users

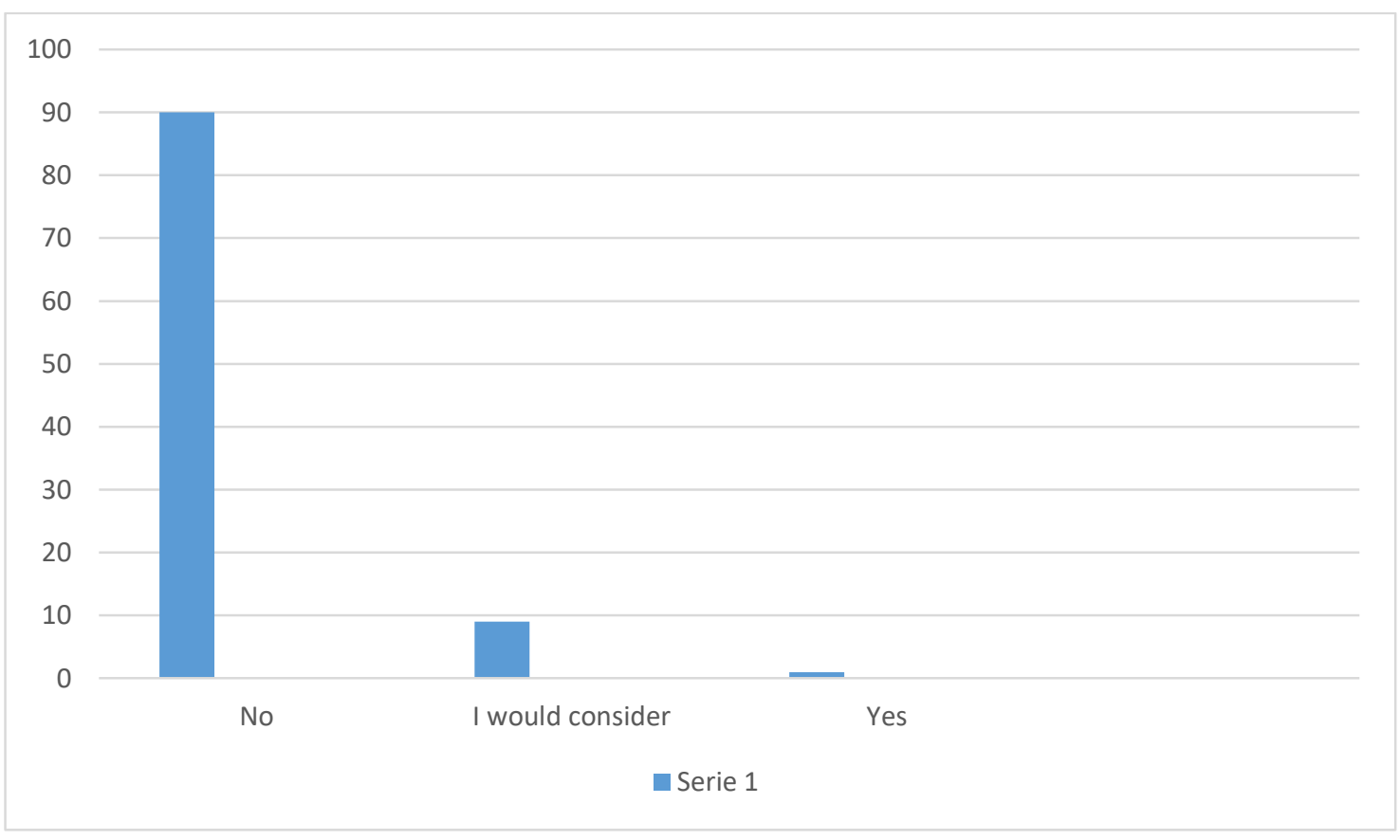

Image 4: Participants influenced by celebrity endorsement on social media

An overwhelming majority of 98 participants out of 100 participants were active on one social networking site at the very least. However, a massive majority of 98 percent of them answered 
in the negative when asked if ever a celebrity endorser had influenced them to buy a cosmetic brand.

Respondents in the current study did not seem to have been swayed by celebrity endorsement though a majority of them were active on at least one social media-networking site. (Kowalczyk \& Pounders, 2016)

Interviewee \#4: “Let me tell you this, I don't think I am going to be influenced even if I get to see these endorsers a lot on social media."

The person who was interviewed was convinced that she would not have been persuaded by a celebrity endorser into buying a certain product.

Another theme that popped in the course of the study was that interviewees' children were playing a key role in increasing their parents' awareness of celebrity endorsement. When they were questioned to cite some names of celebrity endorsers of luxury cosmetic products, $20 \%$ respondents said they were conscious of the younger crop of celebrity endorsers thanks to their children's recognition of them:

Interviewee \#1: "And because of my daughter I know about Zoella and she gets paid to endorse cosmetic products."

Interviewee \#2: “Lily-Rose Deep, Johnny Depp's daughter, it seems, backs a perfume or so, my daughter tells me. So wanted me to buy her that for birthday. And, yes, I did." 
Respondents admitted that celebrity endorsers were indeed an influence on their children and, further, that they were in the habit of purchasing such endorsed products for their children. It was stated earlier, pre-existing studies reveal younger people were more disposed to let themselves influence by celebrity endorsers. Even so, the current research suggests that their children's recognition of celebrity endorsers does exert some influence on the buying decisions of mature female consumers in the 40-60 demographic though in all certainty they themselves were not directly influenced (Chan et al., 2013). 
The online survey and interview were framed with the idea of identifying the various characteristics or features of a celebrity endorser of luxury cosmetic brands that consumers thought were important to their buying decision. The survey posed the question 'Which attributes in a celebrity endorser would you consider as most important for a luxury cosmetics brand?' and asked respondents to rank these qualities on a scale of 1 to 3 , " 1 " being most important and " 3 ", least important'. Seno \& Lukas (2007) point to expertise, physical attractiveness, and trustworthiness as some of the most critical attributes of a celebrity endorser.

\section{Features of celebrity endorsement}

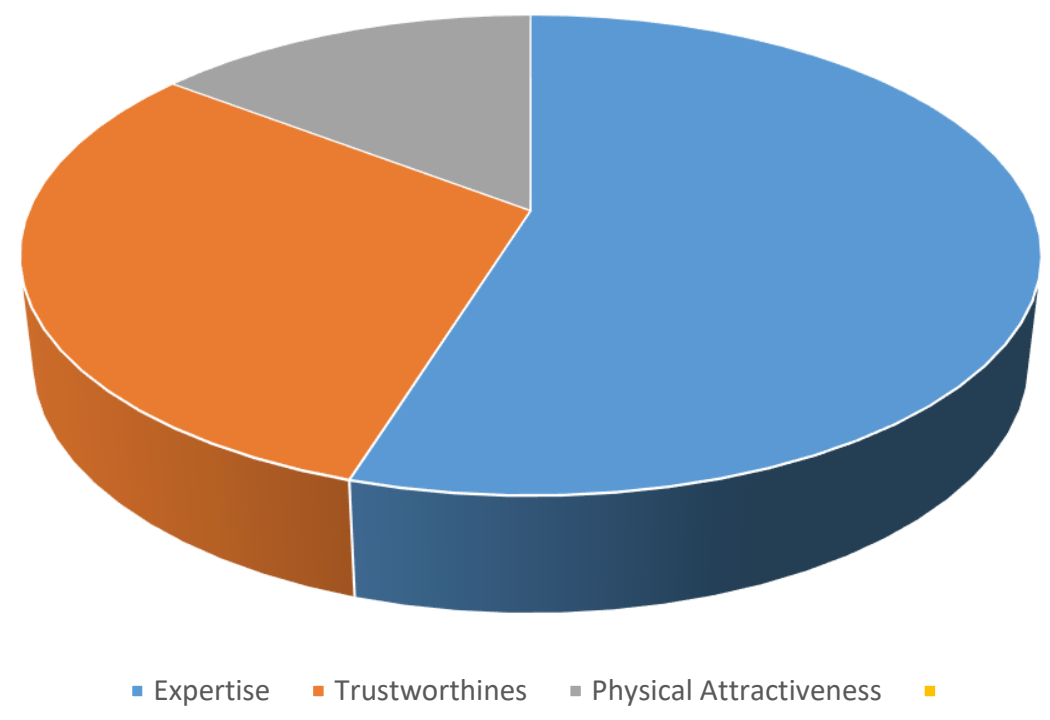

Image 5: Features (Attributes) of a celebrity endorser of luxury cosmetic brands

As shown in the Image 5, a majority of respondents identified expertise as the most important feature that a celebrity endorser ought to have in order to be effective and successful. Luxury cosmetics brands select celebrities who utilise the product, such 
that the target market deems them credible or is influenced by the endorser's expertise. (Hoyer et al., 2018) Respondents to the online survey were also questioned: 'Which kind of profession in a celebrity [model, singer, actress, or reality television star] would you be more disposed to trust when endorsing a luxury cosmetic product?' as shown in the Image 6, the most trusted profession is that of an actress, followed by that of a model:

\section{Professions}

1,2

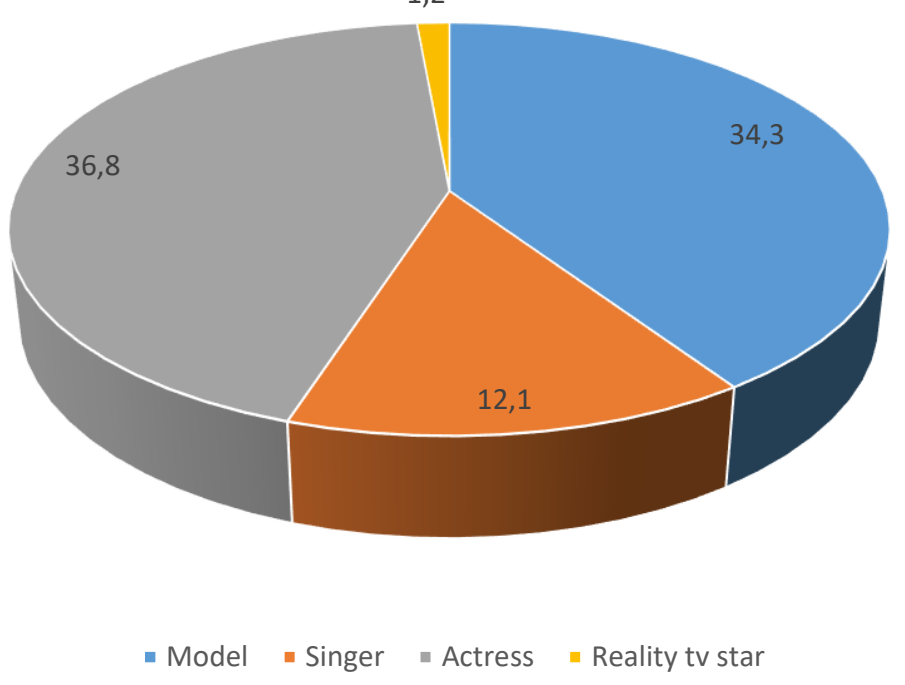

Image 6: Trusted professions.

The above findings are in sync with the theory set forth by Hoyer et al. (2018), as well as Seno and Lukas (2007) that a credible endorser is one whose persona effectively intersects expertise and trustworthiness. The researchers discovered consumers are more likely to trust celebrities with a certain level of perceived expertise in relation to the product under consideration. This expertise was deemed by respondents to come from the celebrities' practical contact with the product in their professional role. 
An oft-recurring theme in the interviews was the appropriateness of the celebrity endorser's age to the product she/he was backing. Three of the people who were interviewed showed a preference of celebrities with an appropriate age:

Interviewee \#2: "Supposing they are endorsing a cosmetic brand then I feel they ought to be appropriate, age-wise I mean, to the kind of audience they are aimed. What is the point otherwise?"

Interviewee \#4: "From my perspective, brands should show consider a certain age range when it comes to picking stars endorsers. Many times, people get too caught up with wishing to be younger than they are. They should probably accept the age they are. And brands should egg them on to do that."

Interviewee \#6: "I think that is important the age like a parameter, and brands should bring in older endorsers."

The study reveal on the fact that people rather prefer to see famous who are closer to their age range endorsing luxury cosmetics. Another conclusion is that brands are increasingly prevailing on consumers to accept their age, rather than obscuring it. Jane and Roy (2016) have narrowed the trust, experience and appeal as key attributes associated with creating a reliable celebrity supporter. Even so, respondents felt the celebrity's age was also a key attribute and endorsers must be age appropriate to the target audience. Alternatively, brands should feature a range of endorsers from different age groups. This means that a celebrity of the same age or belonging to the same age group as they can affect this sample. 
The structured interview comprised questions aimed at capturing the perception of the ideal-self of the people who were interviewed and whether or not they purchase luxury cosmetic brands that correlate their ideal-self. The terms 'self-concept' and 'ideal-self' were defined for the benefit of the participants prior to the interview.

90 percent of respondents seemed confident that they were able to identify their ideal-self. A pivotal theme that emerged from this discourse was that the respondents' ideal-self consisted in appearing younger in the eyes of others:

Interviewee \#1: "Yes, I think I buy cosmetics mostly to look younger than what I am, I must admit. Therefore, I think my idealself is to be a younger. Because I am conscious that I am getting older and want to show a younger image."

Interviewee \#8: "Certainly, I would like to look younger than what I am. To feel youthful and look nicer, I do my makeup and hairstyle every day and once a week I'm going to a professional stylist."

Authors think luxury cosmetic brands stand to gain the most value by targeting their ads at consumers' ideal-self. Quite many respondents in the current study acknowledged that they were desirous of appearing younger in the eyes of friends and colleagues and their luxury cosmetics purchases were driven by this intent. They purchase cosmetics that correspond to their ideal-self. People 
who were interviewed declare that purchased lotions to keep their skin younger- and healthier-looking. One of the respondents said:

Interviewee \#7: "Because they are kind of rejuvenating brands, I buy Dior and Guerlain. And yes, I do want to look and feel younger deep inside than what I am. Having young daughters does impact my selections."

This is very much in step with literature as interviewee \#7 was quite conscious that she buys the luxury cosmetic products that resonate with her ideal-self. Hence, it can be inferred that this pool of mature women buy cosmetics that relate to the image they want to build and nurture in others' eyes. Only one interviewee bought a brand that related to her ideal-self, namely, Dior and Guerlain. By contrast, the other respondents bought products - like anti-wrinkle formulas and moisturisers that they thought were in synch with ideal-selves. 


\subsection{SELF CONCEPT CLARITY MODEL}

A new theme surfaced from the responses to the interview question - 'When it comes to buying luxury cosmetic products or following skincare trends, do you look to celebrities for inspiration? Or is there any other reason why you follow celebrities?' and this was in line with much of the literature around the self-concept clarity model. Consumers who score low in the SCC model tend to be younger and still working on developing their own style and appearance. Such low scorers are inclined to be less confident about their self (Soneji et al, 2015). The responses of many interviews corresponded with this body of literature:

Interviewee \#3: "I think new generations are more likely to keep a tab on celebrity trends compared to older people my age. As a matter of course, I don't follow celebrities but just in case, I come across a style and that catches my eye, I would try it out for sure."

Interviewee \#7: "No I don't. Though my daughters do."

Through close association and contact ("ruboff effect") with younger members in their family, the respondents realized that younger people are increasingly inspired in the matter of appearances and styles by celebrities. This having been said, all ten interviewees, when asked if they search celebrities for inspiration in relation to luxury cosmetics, answered in the negative:

Interviewee \#6: “I don't, I like to believe I have my own style. On television or in a magazine, if I see a celebrity with a lovely look, 
I might think of trying it out. That doesn't mean I go out my way to get draw inspiration from them."

This leads to the belief that these women would mark high in the self-concept clarity model since they don't seem to look to celebrities for cues or inspiration when it comes to their own appearance. Far from being influenced by celebrity trends, they seem confident with their own evolved style. (Soneji et al., 2015). 


\subsection{CONGRUENCE}

In order to study the congruence, the people interviewed were asked to identify the features they think of in connection with the celebrity endorsers, namely, Monica Bellucci, Liv Tyler, and Carla Bruni. Next, the respondents were asked the same question, this time in relation to the luxury brands the same celebrities were endorsing: Dior, Givenchy and Chanel. 
An overwhelming number of respondents assigned the most favourable features to Carla Bruni and Monica Bellucci. They tended to focus more on the positive personality characteristics, like 'trustworthy, caring, approachable and intelligent,' rather than the outward form in case of Carla Bruni and Monica Bellucci. By contrast, they chose to associate negative characteristics with Liv Tyler because her father is Steven Tayler, singer of rock group Aerosmith, and there is a transfer between father and daughter.

These responses closely correspond to Choi and Rifon's (2012) congruence model, which proposes that consumers who are in harmony with the celebrity have tendency to also be favourably disposed to the brand. When asked - "Which celebrity endorser would you connect to the most (particularly in style, attributes, etc.) and why?" - all of the respondents said they believed that it is to Carla Bruni and Monica Bellucci that they related the most:

Interviewee \#8: "I identify most to, eh...Carla Bruni. At least, I think so. And, she's more or less my age."

Interviewee \#4: "I probably identify most to Monica Bellucci. Have seen many of her movies, so I think I know her a little better than the others."

Interviewee \#10: "“l'd probably identify most to Carla Bruni. We are exactly the same age. And have a similar style too."."

When questioned to define their ideal-self, more than 50 percent of respondents said their ideal-self consists in appearing 
younger; so, respondents in the current study find common ground with celebrities of the same age. In addition, they associate positively ('trustworthy, professional and intelligent') with a celebrity they relate to the most, which is further indication that they consider such celebrities as credible endorsers (Ashman et al., 2015). 
As a next step, respondents were demanded to attribute characteristics to the brands under consideration: Chanel, Dior and Givenchy.

People regarded all Dior, Givenchy and Chanel as goodquality, long-established and pricy luxury brands. At the same time, the last one, Chanel were considered more accessible and affordable. Later on, interviewees were questioned to consider whether or not the celebrities represent a right-fit for the respective brand they were endorsing (Dwivedi et al., 2015). Barring 4 respondents, the rest all thought that Liv Tylor did match Givenchy:

Interviewee \#1: “... and I think Liv Tyler, is not good for Givenchy brand image because she looks more young."

Interviewee \#9: "The last one seems less usual. Looks like they are trying to woo the younger lot of consumers because I think that she is younger, but I'm not sure about that because is less know."

According to Halonen-Knight and Hurmerinta (2010), a celebrity who is not in synch with the brand she/he is endorsing might have an off-putting effect on the consumer, thus repelling them from the brand. In the course of this study, almost half of mature female consumers seemed to echo this sentiment because they surmised that Givenchy was not keen on their market since the brand had a younger celebrity endorsing it. Quite a few respondents felt the brand's (perceived) preference for younger users was "putting them off" from buying Givenchy cosmetic. 
Another theme brought to the fore by this study was that any negative publicity around a celebrity endorser did not seem to have any impact on respondents or their buying decision. As in 2016, Jain and Roy's study was inconclusive about whether or not a celebrity's negative associations were transmitted to the product backed by her/him. However, the current research has thrown light on the fact that buyers do not relate or internalise the negative publicity enveloping a celebrity endorser arising from, say, a scandal of some sort:

Interviewee \#8: "Never. What does a celebrity's private life have to do with the brands she is endorsing?"

A majority of respondents in the study admitted they would still go ahead and purchase a certain luxury cosmetic regardless of any bad publicity around the endorser. This aligns with the ideas of Halonen-Knight and Humerinta (2010) Respondents said that negative associations from the celebrity did not move to the brand or impinge on its public perception. 
In sum, the research objectives were systematically looked into within this research, and, furthermore, suitably correlated with the existing body of literature on the theme. A key conclusion was that female luxury cosmetic consumers show a keen awareness around celebrity endorsed ads, no matter if these are in stores and magazines or on television. Even so, their awareness of celebrity endorsed ads online was low, though 98 of the 100 questionnaire participants were on at least one social networking site.

Expertise and trustworthiness were most important characteristics mature female consumers looked for in the celebrity endorser, though a majority of them felt, as evidenced by their interviews and questionnaire responses, the celebrity endorser should also be age appropriate to the target market for the ad. The same thought came up on another occasion, that is, when examining the compatibility between the consumer and the celebrity endorser; the study found that respondents were more likely to relate to celebrities of more or less the same age as themselves like Carla Bruni and Monica Bellucci.

On the contrary, when questioned to call to mind their idealself, the respondents seem to want to appear younger and more confident in the eyes of friends and colleagues; they routinely used luxury cosmetics like anti-ageing lotions as well as makeup in order to look younger. The implication is that mature female consumers use luxury cosmetics with a view to look younger, and their buying decisions are not influenced by celebrity endorsers who match their ideal-self. 
CONCLUSIONS, LIMITATIONS AND RECOMMENDATIONS 
This chapter wraps up this research on how celebrity endorsement influences the buying behaviour of mature female consumers in the luxury cosmetics market. By using descriptive design methods that enable collection of comprehensive and thorough data around the interpretations of self-concept and congruence, the study presents real-world and large-scale indications of how celebrity endorsers influence consumers. The chapter is designed to provide independent answers to each research objective and concludes with some actionable recommendations for the future. 
Implicit celebrity endorsement was considered most effective and influential with consumers, as per the research. The focus of others studies has been younger people; this opened up the possibility to study the recognition level and preferences of older demographics in the matter of celebrity endorsement.

The respondents were acutely conscious of in-store and journal ads, though the major part of them didn't seem to have been persuaded by celebrity endorsers into buying luxury cosmetics. A few respondents acknowledged there were more conscious of celebrity endorsers, something attributable to celebrity endorsers' influence on respondents' children. The result was that such respondents bought celebrity-endorsed products for their children. A key finding here was that respondents were indeed buying celebrity-endorsed products though they themselves were not directly influenced by the celebrity.

In addition, responses to the online survey revealed that product quality was the factor respondents overwhelmingly weighed in when buying a cosmetic; in stark contrast, the celebrity endorser was considered the least important factor. Also, responses in several earlier research on younger people indicate participants would like to see more of implicit advertising, particularly where the celebrity endorser suggests that she/he is also a user of the said product.

Respondents scored low in terms of their awareness of celebrity endorsers, quite surprising since a few of them were on 
social media and quite engage at that. This calls for more research to identify the causes of low recognition of celebrity-endorsed ads on social networks and ways luxury cosmetic brands can fine-tune their targeting of mature female consumers on social networking sites. 
According to existing literature, expertise, trustworthiness and attractiveness were the key characteristics that informed the credibility of the celebrity endorser. Nevertheless, the relative importance of these characteristics might vary from one consumer to another. The aim of the current study was to establish the features of celebrity endorsers that mature female consumers deemed important, as well as any additional attributes that they thought were relevant. The online survey served as an effective tool for bringing these characteristics to light.

The questionnaire found that mature female consumers had a greater chance of trusting celebrities, given their experience with luxury cosmetic brands, a discovery that matched the observation in current literature that credible endorsers often came with a mix of expertise and trustworthiness.

Apart from expertise, consumers also thought the endorser's age was a key feature, as revealed by interviews and questionnaires. Consumers' favourable disposition toward the Dior ad featuring Monica Bellucci, who was in the same age group as them, mirrored this sentiment. The broader implication is that it's time luxury brands began considering including multiple celebrity endorsers belonging to different age groups in their ads, so as to be able to appeal to more numbers of mature consumers. 
According to Castro \& Marquez (2017), luxury brands stand to benefit the most by targeting a consumer's ideal-self. The interviews used in the current study helped flesh out the respondents' perception of their idea-self.

The answers of the interviews gave rise to another theme that helped fathom out the female consumers' ideal-self. It appears that their ideal-self was a younger and fresh look they desired to show to others, which, in turn, influenced their luxury cosmetics choices and purchases.

As stated earlier, the research sample also believed that they were more likely to be swayed by a celebrity endorsers belonging in the same age group as themselves. So age appropriateness also figured as an important feature of the celebrity endorser, a feature that corresponded to the consumers' actual-self rather than their ideal-self. 
Lastly, celebrity and brand congruence were estimated. During the interview, the researcher displayed images of four celebrity endorsed ads to the respondents and then gathered their feedback.

The most part of participants associated Carla Bruni and Monica Bellucci with positive features. Not surprisingly, these were the celebrities who were connected with the most. This bring to a favourable disposition towards the luxury brand endorsed by them. Chanel was associated with good quality, high-price and well established, but not model Carla Bruni, the celebrity fronting the brand. Interviewees thought pairing a younger celebrity endorser with an older, good-quality brand resulted in an incongruent promotion. In short, ensuring congruence between the consumer's actual-self and the celebrity and between celebrity and the brand is key to fostering favourable customer responses towards both the brand and the ad. 
In its essence, celebrity endorsement does not exert a great deal of influence on the buying decisions of mature female consumers in the luxury cosmetics market under consideration. The following table gives the outcomes of each objective at a glance:

\begin{tabular}{|c|c|}
\hline $\begin{array}{l}\text { OB1: Examine the awareness or recognition level of } \\
\text { mature female consumers with respect to celebrity } \\
\text { endorsement campaigns by luxury cosmetic brands }\end{array}$ & $\begin{array}{l}\text { There is high recognition of celebrity endorsed ads in-store and in magazines; even so, they do not } \\
\text { seem to influence consumers to such extent as to persuade them into buying the endorsed brand. } \\
\text { Surprisingly, there is low recognition of online celebrity- endorsed ads despite the fact that the most part } \\
\text { of respondents are active on at least one social networking platform. }\end{array}$ \\
\hline $\begin{array}{l}\text { OB2: Identify the features that they deem most } \\
\text { credible in a celebrity endorser (trustworthiness, expertise, } \\
\text { and attractiveness). }\end{array}$ & $\begin{array}{l}\text { Expertise is valued as the most important feature in a celebrity endorser. In addition, } \\
\text { respondents in the mature luxury cosmetic market preferred the endorsers to be of similar age as } \\
\text { themselves, which means they also hold the endorser's age as an important characteristic. }\end{array}$ \\
\hline $\begin{array}{l}\text { OB 3: Examine how mature female consumers } \\
\text { perceive their own ideal self and whether the luxury cosmetic } \\
\text { brands they buy are in synch with this ideal self }\end{array}$ & $\begin{array}{l}\text { They perceive clearly their ideal self and desire to appear younger to others. The ads that target } \\
\text { their self are more attractive than the ads that target the ideal self. }\end{array}$ \\
\hline $\begin{array}{l}\text { OB 4: Analyse, using aspects of the match-up } \\
\text { hypothesis, from the standpoint of mature female } \\
\text { consumers, whether luxury cosmetic brands are successfully } \\
\text { choosing appropriate celebrities to endorse their brand. }\end{array}$ & $\begin{array}{l}\text { Respondents thought Monica Bellucci endorsing Dior was an instance of a congruent ad, and, } \\
\text { overall, they seem to warm up and view in favourable light ads that related to their actual self. }\end{array}$ \\
\hline
\end{tabular}

Table 2: Achieved objectives

The current research shows that mature females in the 40-60 demographic are more likely to approve of celebrity endorsers who they can clearly connect with. Therefore, luxury cosmetic brands in this buyer segment would stand to benefit if they increasingly 
target their promotional towards the actual-self rather than the ideal-self of their intended audience. And while they are at it, brands are recommended to bring such celebrity endorsers into play who are in the same or similar age group as the target market. In addition, in order that the endorser is perceived as credible, brands must strive to imply (implicit advertising) that she/he is also a user of the product under consideration.

The research was carried out on a small sample comprising 10 interviewees and 100 online questionnaire participants; it is now proposed that the same study should be conducted on a larger scale to frame application-oriented general concepts around how celebrity endorsers influence mature female buyers. Mature female consumers have a significant presence on various social media platforms, so it is recommended that conclusions of this study should be used as a beachhead to launch further studies on how to amplify the effect of celebrity endorsement on social media users in this age group.

The small sample size of this research proved a key limitation since it resulted in rather weak generalisations around how celebrity endorsers influence the buying behaviour of mature female consumers in the luxury cosmetics market. Also, the structured and standardised interviews didn't provide room for further exploratory questions that might have helped gather more in-depth and granular data on respondents' opinions and values. Hence, there was no scope for any further exploration of existing literature on celebrity endorsement. 
En esencia, el respaldo de las celebridades no ejerce una gran influencia en las decisiones de compra de las consumidoras maduras en el mercado de cosméticos de lujo considerado. La siguiente tabla muestra los resultados de cada objetivo de un vistazo:

\begin{tabular}{|c|c|}
\hline $\begin{array}{l}\text { OB1: Examinar el nivel de conocimiento } 0 \\
\text { reconocimiento de las consumidoras maduras con respecto } \\
\text { a las campañas de celebrity endorsement por parte de } \\
\text { marcas de cosméticos de lujo. }\end{array}$ & $\begin{array}{l}\text { Existe un gran reconocimiento de los anuncios con celebrity endorsed tiendas y revistas; aun asi, } \\
\text { no parecen influir en los consumidores hasta el punto de persuadirlos de que compren la marca } \\
\text { promocionada. Sorprendentemente, hay poco reconocimiento de los anuncios en línea con celebrity- } \\
\text { endorsed a pesar de que la mayoria de los encuestados están activos en al menos una plataforma de } \\
\text { redes sociales. }\end{array}$ \\
\hline $\begin{array}{l}\text { OB2: Identificar las caracteristicas que consideran } \\
\text { más creible en un celebrity endorser (confiabilidad, } \\
\text { experiencia y atractivo). }\end{array}$ & $\begin{array}{l}\text { La experiencia se valora como la caracteristica más importante de un celebrity endorser. Además, } \\
\text { las encuestadas en el mercado de los cosméticos de lujo para personas maduras preferian que los } \\
\text { endorsers tuvieran una edad similar a la de ellas, lo que significa que también consideran la edad del } \\
\text { endorser como una caracteristica importante. }\end{array}$ \\
\hline $\begin{array}{l}\text { OB 3: Examinar cómo las consumidoras maduras } \\
\text { perciben su propio yo ideal y si las marcas de cosméticos de } \\
\text { lujo que compran están en sintonia con este yo ideal. }\end{array}$ & $\begin{array}{l}\text { Perciben claramente su yo ideal y desean parecer más jóvenes a los demás. Los anuncios que se } \\
\text { dirigen a si mismos son más atractivos que los anuncios que se dirigen al yo ideal. }\end{array}$ \\
\hline $\begin{array}{l}\text { OB 4: Analizar, desde el punto de vista de las } \\
\text { consumidoras maduras, si las marcas de cosméticos de lujo } \\
\text { están eligiendo con éxito celebridades adecuadas para } \\
\text { respaldar su marca. }\end{array}$ & $\begin{array}{l}\text { Los encuestados pensaron que el hecho de que Mónica Bellucci respaldara a Dior era un ejemplo } \\
\text { de un anuncio congruente y, en general, parecen ver anuncios claros favorables que se relacionan con su } \\
\text { yo real. }\end{array}$ \\
\hline
\end{tabular}

Tabla 2: Objetivos alcanzados

La investigación actual muestra que las mujeres maduras en el grupo demográfico de 40 a 60 años tienen más probabilidades de aprobar a los patrocinadores famosos con los que pueden 
conectarse claramente. Por lo tanto, las marcas de cosméticos de lujo en este segmento de compradores se beneficiarían si orientaran cada vez más su promoción hacia el yo real en lugar del yo ideal de su público objetivo. Y mientras lo hacen, se recomienda a las marcas que pongan en juego a los patrocinadores famosos que están en el mismo grupo de edad o similar al del mercado objetivo. Además, para que el patrocinador sea percibido como creíble, las marcas deben esforzarse por dar a entender (publicidad implícita) que él o ella también es un usuario del producto en cuestión.

La investigación se llevó a cabo en una pequeña muestra compuesta por 10 entrevistados y 100 participantes del cuestionario en línea; se propone ahora que el mismo estudio debe llevarse a cabo a una escala mayor a los conceptos generales orientados a la aplicación del marco en torno a cómo influyen celebridad endosantes madurar los compradores de sexo femenino. Madurar las consumidoras tienen una presencia significativa en varias plataformas de medios sociales, por lo que se recomienda que las conclusiones de este estudio deben ser usados como una cabeza de playa para poner en marcha nuevos estudios sobre cómo amplificar el efecto de la celebridad de los usuarios de medios sociales en este grupo de edad.

El pequeño tamaño de la muestra de esta investigación demostró ser una limitación clave, ya que dio lugar a generalizaciones bastante débiles sobre cómo los patrocinadores famosos influyen en el comportamiento de compra de las consumidoras maduras en el mercado de cosméticos de lujo. Además, las entrevistas estructuradas y estandarizadas no 
proporcionaron espacio para más preguntas exploratorias que podrían haber ayudado a recopilar datos más detallados y granulares sobre las opiniones y los valores de los encuestados. Por lo tanto, no había margen para una mayor exploración de la literatura existente sobre el respaldo de celebridades. 
En essència, el suport de les celebritats no exerceix una gran influència en les decisions de compra de les consumidores madures en el mercat de cosmètics de luxe considerat. La següent taula mostra els resultats de cada objectiu d'una ullada:

\begin{tabular}{|c|c|}
\hline $\begin{array}{l}\text { OB1: Examinar el nivell de coneixement } 0 \\
\text { reconeixement de les consumidores madures respecte a les } \\
\text { campanyes de celebrity endorsement per part de marques } \\
\text { de cosmètics de luxe. }\end{array}$ & $\begin{array}{l}\text { Existeix un gran reconeixement dels anuncis amb celebrity endorsed botigues i revistes; aixi i tot, } \\
\text { no semblen influir en els consumidors fins al punt de persuadir-los que compren la marca promocionada. } \\
\text { Sorprenentment, hi ha poc reconeixement dels anuncis en linia amb celebrity-endorsed a pesar que la } \\
\text { majoria dels enquestats estan actius en almenys una plataforma de xarxes socials. }\end{array}$ \\
\hline $\begin{array}{l}\text { OB2: Identificar les caracteristiques que consideren } \\
\text { més creible en un celebrity endorser (confiabilitat, } \\
\text { experiència i atractiu). }\end{array}$ & $\begin{array}{l}\text { L'experiència es valora com la característica més important d'un celebrity endorser. A més, les } \\
\text { enquestades en el mercat dels cosmètics de luxe per a persones madures preferien que els endorsers } \\
\text { tingueren una edat similar a la d'elles, la qual cosa significa que també consideren l'edat del endorser com } \\
\text { una característica important. }\end{array}$ \\
\hline $\begin{array}{l}\text { OB 3: Examinar com les consumidores madures } \\
\text { perceben el seu propi jo ideal i si les marques de cosmètics } \\
\text { de luxe que compren estan en sintonia amb aquest jo ideal. }\end{array}$ & $\begin{array}{l}\text { Perceben clarament el seu jo ideal i desitgen semblar més joves als altres. Els anuncis que es } \\
\text { dirigeixen a si mateixos són més atractius que els anuncis que es dirigeixen al jo ideal. }\end{array}$ \\
\hline $\begin{array}{l}\text { OB 4: Analitzar, des del punt de vista de les } \\
\text { consumidores madures, si les marques de cosmètics de luxe } \\
\text { estan triant amb èxit celebritats adequades per a donar } \\
\text { suporta la seua marca. }\end{array}$ & $\begin{array}{l}\text { Els enquestats van pensar que el fet que Mónica Bellucci donara suport a Dior era un exemple } \\
\text { d'un anunci congruenti, en general, semblen veure anuncis clars favorables que es relacionen amb el seu } \\
\text { jo real. }\end{array}$ \\
\hline
\end{tabular}

La investigació actual mostra que les dones madures en el grup demogràfic de 40 a 60 anys tenen més probabilitats d'aprovar als patrocinadors famosos amb els quals poden connectar-se 
clarament. Per tant, les marques de cosmètics de luxe en aquest segment de compradors es beneficiarien si orientaren cada vegada més la seua promoció cap al jo real en lloc del jo ideal del seu públic objectiu. I mentre ho fan, es recomana a les marques que posen en joc als patrocinadors famosos que estan en el mateix grup d'edat o similar al del mercat objectiu. A més, perquè el patrocinador siga percebut com a creïble, les marques han d'esforçar-se per donar a entendre (publicitat implícita) que ell o ella també és un usuari del producte en qüestió.

La investigació es va dur a terme en una xicoteta mostra composta per 10 entrevistats i 100 participants del qüestionari en línia; es proposa ara que el mateix estudi ha de dur-se a terme a una escala major als conceptes generals orientats a l'aplicació del marc entorn de com influeixen celebritat endossants madurar els compradors de sexe femení. Madurar les consumidores tenen una presència significativa en diverses plataformes de mitjans socials, per la qual cosa es recomana que les conclusions d'aquest estudi han de ser usats com un cap de platja per a posar en marxa nous estudis sobre com amplificar l'efecte de la celebritat dels usuaris de mitjans socials en aquest grup d'edat.

La xicoteta grandària de la mostra d'aquesta investigació va demostrar ser una limitació clau, ja que va donar lloc a generalitzacions bastant febles sobre com els patrocinadors famosos influeixen en el comportament de compra de les consumidores madures en el mercat de cosmètics de luxe. A més, les entrevistes estructurades $i$ estandarditzades no van proporcionar espai per a més preguntes exploratòries que podrien 
haver ajudat a recopilar dades més detallades i granulars sobre les opinions i els valors dels enquestats. Per tant, no hi havia marge per a una major exploració de la literatura existent sobre el suport de celebritats. 
REFERENCES 


\section{CHAPTER 7 - REFERENCES}

Apaolaza, V. \& Hartmann, P. (2007). La satisfacción de las consumidoras con las marcas cosméticas: el impacto de las dimensiones utilitaria y emocional de la marca. Congreso Aemark.

Ashman, R., Solomon, M., Wolny, J., (2015) An old model for a new age: Consumer decision making in participatory digital culture. Journal of Customer Behaviour, 14(2): 127-146. DOI:10.1362/147539215X14373846805743.

Bafna, A., Gandhi, P., Jain, A., Dantara, V., Desai, K.P., Dholakiya, M., Gurnani, N., Gagnani, P., Udhani, D., Keswani, K. \& Kanabar, H. (2016). Influence of celebrity endorsements on the consumer behavior for facial care product. Imperial Journal of Interdisciplinary Research (IJIR), 2, Issue-5. [12th January 2020]

Baxter, K., Courage, C. \& Caine, K. (2015). Understanding Your Users: A Practical Guide to User Research Methods. 2nd Ed. Morgan Kaufmann.

Belch, G.E. \& Belch, M.A. (2013). A content analysis study of the use of celebrity endorsers in magazine advertising. International Journal of Advertising, 32(3): 369-389.

Biswas, S., Hussain, M. \& O'Donnell, K. (2009). Celebrity Endorsements in Advertisements and Consumer Perceptions: A Cross-Cultural Study. Journal of Global Marketing, 22(2): 121-137. DOI: $10.1080 / 08911760902765940$.

Blumberg, B., Cooper, R. D. \& Schindler, S. P., (2014). Business Research Methods. 4th Ed. Maidenhead, McGraw-Hill Education. 
Boon, S. D. \& Lomore, C. D. (2001). Admirer-celebrity relationships among young adults: Explaining perceptions of celebrity influence on identity. Human Communication Research, 27: $432-465$.

Boon-Long, S. \& Wongsurawat, W. (2015). Social media marketing evaluation using social network comments as an indicator for identifying consumer purchasing decision effectiveness. Journal of Direct Data and Digital Marketing Practice, 17(2): 130-149.

Brand Finance, (2020). https://brandirectory.com/consumerresearch/

Bryman, A. \& Bell, E. (2011). Business Research Methods. 3rd Ed. Oxford University Press.

Burns, B. R. \& Burns, A. R. (2008). Business Research Methods and Statistics using SPSS. 1st Ed. SAGE Publications Ltd.

Caldwell, G. (2019). Beauty Industry Contributed $£ 28.4$ Billion To UK Economy In 2018 - Global Cosmetics News, Global Cosmetics News. https://www.globalcosmeticsnews.com/beauty-industrycontributed-28-4-billion-to-uk-economy-in-2018/ [10 September 2020].

Castro, L. \& Marquez, J. (2017). The use of Facebook to explore self-concept: analysing Colombian consumers. Qualitative Market Research: An International Journal, 20 (1): 43 - 59. Dol: 10.1108/QMR-12-2015-0086 [12th January 2020].

Centocchi, C. F. (2007). Una aproximación a la publicidad cómplice actual: cuando las celebrities dejan de alabar. Pensar La Publicidad. Revista Internacional De Investigaciones Publicitarias. 1(1): 219 - 234. https://dx.doi.org/10.5209/PEPU 
Chan, K., Leung N., Y. \& Luk, E.K. (2013). Impact of celebrity endorsement in advertising on brand image among Chinese adolescents. Young Consumers, 14(2): 167-179. https://doi.org/10.1108/17473611311325564

Choi, S. M. \& Rifon, J. N. (2012). It is a match: The impact of congruence between celebrity image and consumer ideal self on endorsement effectiveness. Psychology and Marketing, 29(9): 639650 [1st December 2019].

Choi, S. M., Lee, W. \& Kim, H. (2005). Lessons from the rich and famous: A cross-cultural comparison of celebrity endorsement in advertising. Journal of Advertising, 34(2): 85-98 [29th November 2019].

Cohan, J. A. (2001). Towards a new paradigm in the ethics of women's advertising. Journal of Business Ethics, 33(4): 323-337.

Collis, J. \& Hussey, R. (2014). Business research: A practical guide for undergraduate and post graduate students. 4 th Ed. Palgrave Macmillan High Education.

Creek,M., Lescrauwaet, R. \& Bowman-Busato,J. (2017). Consumers Insights 2017. Cosmetics Europe Expert Group. https://cosmeticseurope.eu/files/6114/9738/2777/CE Consumer I nsights 2017.pdf

Dior. https://www.dior.com/es es

Dwivedi, A., Johnson, L.W. \& McDonald, R.E. (2015). Celebrity endorsement, self-brand connection and consumer-based brand equity. Journal of Product \& Brand Management, 24(5): 449-461. https://doi.org/10.1108/JPBM-10-2014-0722 [21st February 2020]. 
Easterby-Smith, M., Thorpe, R. \& Jackson, P. (2012). Management Research. 4th Ed. SAGE Publications Ltd.

Egan, J. (2007). Marketing Communications. Cengage Learning.

Enis, B.M. (1974). Marketing principles: The management process. Goodyear Publishing Company, Universidad de Michigan.

Farrell, A. K., Karels, V. G., Montfort, W. K. \& McClatchey, A. C. (2000). Celebrity performance and endorsement value: The case of Tiger Woods. Managerial Finance, 26(7): 1-15 [23rd Novemeber 2019].

Fill, C. (2013). Marketing Communications: Brands, Experiences and Participation. 6th Ed. Pearson Education, Inc.

Ghauri, P. \& Gronhaug, K. (2005). Research Methods in Business Studies: A Practical Guide. 3rd Ed. Pearson Education Limited.

Gill, J. \& Johnson, P. (2010). Research Methods for Managers. 4th Ed. SAGE Publications Ltd.

GlobalData, (2019). TrendSights Analysis: Image Consciousness; Exploring consumers' attitudes towards image and beauty. UK: GlobalData. [1st March 2020]. https://www.globaldata.com/store/report/cs0053ts--trendsightsanalysis/

Goldsmith, E. R., Moore, M. A. \& Beaudoin, P. (1999). Fashion innovativeness and self-concept: a replication. Journal of Product \& Brand Management, 8(1): 7 - 18 [1st December 2019].

Government UK. (2018). The Data Protection Act. GOV.UK. [1st June 2019]. https://www.gov.uk/data-protection 
Graeff, R. T. (1996). Using promotional messages to manage the effects of brand and self-image on brand evaluations. Journal of Consumer Marketing, 13 (3): $4-18$.

\section{Gyvenchy. https://www.givenchy.com/es/en/homepage}

Halonen-Knight, E. \& Hurmerinta, L. 2010. Who endorses whom? Meanings transfer in celebrity endorsement. Journal of Product \& Brand Management, 19 (6): 452 - 460. [17th December 2019].

Heine, K. (2012). The Concept of Luxury Brands. B. Goldmann \& K. Vredenburgh, Eds.; 2nd Ed.

Hodge, A. C., González Romo, Z., García Medina, I. \& FiondaDouglas, A. (2015). Consumer-brand relationships within the luxury cosmetic domain. Journal of Brand Management, 22(8): 631-657. https://doi.org/10.1057/bm.2015.36

Hoffman, T. R. (2007). Image Manipulation: Photoshop as a data-measurement tool (Unpublished master's thesis). University of Nevada, Las Vegas. https://digitalscholarship.unlv.edu/rtds/2291/

Hollensen, S. \& Schimmelpfennig, C. (2013). Selection of celebrity endorsers: A case approach to developing an endorser selection process model. Marketing Intelligence \& Planning, 31(1): $88-102$ [14th January 2020].

Hood, M. (2012). The Tiger Woods scandal: a cautionary tale for event studies. Managerial Finance, 38(5): 543 - 558.

Hoyer, W. D., Maclnnis, D. J. \& Pieters, R. (2018). Consumer Behaviour. 7th Ed. South-Western Cengage Learning. 
Hsu, C. \& McDonald, D. (2002). An examination on multiple celebrity endorsers in advertising. Journal of Product \& Brand Management, 11(1): 19 - 29. [22th November 2019]

Hudders, L., Pandelaere, M. \& Vyncke, P. (2013). Consumer meaning making: The meaning of luxury brands in a democratized Iuxury world. International Journal of Market Research, 55(1): 6990. DOI: $10.2501 /$ IJMR-2013-036.

Hugosson, O., Matthys, C. \& Phung, L. (2014). Perception of the celebrity endorser: A study of how age and gender influences the consumer perception. Jonkoping International Business School.

Hultén, P. \& Vanyushyn, V. (2014). Promotion and shoppers' impulse purchases: the example of clothes. Journal of Consumer Marketing, 31(2): 94 - 102. [20rd February 2020].

IBISworld, 2016. Cosmetics \& Toiletries Retailers in the UK: Market Research Report. IBISworld. [27th February 2020]. https://www.ibisworld.co.uk/market-research/cosmeticstoiletries-retailers.html

llicic, J. \& Webster, M. C. (2015). Consumer values of corporate and celebrity brand associations. Qualitative Market Research: An International Journal, 18(2): 164 - 187. [12th December 2019].

Ingavale, D. (2016). Celebrity endorsement of cosmetics: a study of consumer's perception and buying preferences. Indian Journal of Applied Research, 6(2): 213-215. ISSN 2249-555X. [4th March 2019].

Iniesta-Alemán, I. (2019). Eficacia de los influencers como recurso publicitario en la estrategia de los anunciantes locales. Ámbitos, Revista Internacional de Comunicación, 46: 149-169. Dol: 
https://doi.org/10.12795/Ambitos.2019.i46.09. [20nd February 2020]

Jain, V. \& Roy, S. (2016). Understanding meaning transfer in celebrity endorsements: a qualitative exploration. Qualitative Market Research: An International Journal, 19: 266-286. DOI: 10.1108/QMR-03-2015-0020.

Jankowicz, A. D. (2007). Business Research Projects. 4 th Ed. South-Western Cengage Learning.

Kastanakis, M. \& Balabanis, G. (2012). Between the mass and the class: Antecedents of the "bandwagon" luxury consumption behaviour. Journal of Business Research - J BUS RES, 65. DOI: $10.1016 / \mathrm{j} . j b u s r e s .2011 .10 .005$.

Kitchen, J.P. \& Proctor, T. (2015). Marketing communications in a post-modern world. Journal of Business Strategy. 36(5): 34 42 .

Knoll, J. \& Matthes, J. (2016). The effectiveness of celebrity endorsements: A meta-analysis. Journal of the Academy of Marketing Science, 45(1): 55-75. https://doi.org/10.1007/s11747$\underline{016-0503-8}$

Kotler, P. \& Keller, K. L. (2020). Marketing Management. 15 th Ed. Prentice Hall.

Kowalczyk, C. \& Pounders, R. K. (2016). Transforming celebrities through social media: the role of authenticity and emotional attachment. Journal of Product \& Brand Management, 25 (4): 345-356 [13th November 2019].

Kumar, P. (2010). Marketing of Hospitality \& Tourism Services. Tata McGraw-Hill Education. 
LaWare, M. R. \& Moutsatsos, C. (2013). For Skin That's Us, Authentically Us: Celebrity, Empowerment, and the Allure of Antiaging Advertisements. Women's Studies in Communication, $36(2): 189-208$.

Lea-Greenwood, G. (2013). Fashion Marketing Communications. 1st Ed. John Wiley \& Sons.

Lee, J. \& Thorson, E. (2008). The Impact of Celebrity-Product Incongruence on the Effectiveness of Product Endorsement. Journal of Advertising Research - JAR, 48. DOI: $10.2501 / \mathrm{S} 0021849908080446$.

Lepkowska-White, E., Parsons, A. \& Ceylan, A. (2014). Cross promotion of web references in print ads. Journal of Research in Interactive Marketing, 8(4): $309-326$.

Leslie, Z. L. (2011). Celebrity in the 21st Century: A Reference Handbook: A Reference Handbook. 1st Ed. ABC-CLIO

Lucarini, F. (2020). The differences between the California Consumer Privacy Act and the GDPR. EUGDPR Academy, EU GDPR Online Consultion Centre. [15th May 2020]. https://advisera.com/eugdpracademy/blog/2020/04/13/gdpr-vsccpa-what-are-the-main-differences/

Luppe, R, Rosato, B., Couy, I., Rodrigues, M., \& Helder, A. (2020). The impact of celebrity endorsement in attitudes of women's buying intention on affordable luxury market. Brazilian Journals of Business, 2(2): 1151-1170.

Macdonald, L., García Medina, I. \& González Romo, Z. (2016). A Study of the Impact of Social Networking Communities on the Consumption of Beauty Luxury Products. IGI Global. DOI: 10.4018/978-1-4666-9958-8.ch009. [15th February 2020]. 
Marshall, D. \& Redmond, S. (2016). A companion to celebrity. John Wiley \& Sons, Inc. DOI: 10.1080/19392397.2016.1204150.

Matzler. K., Bauer, A. \& Mooradian, A. T. (2015). Self-esteem and transformational leadership. Journal of Managerial Psychology, 30(7): 815 - 831 [11st December 2019].

McCracken, G. (1989). Who is the Celebrity Endorser? Cultural Foundations of the Endorsement Process. Journal of Consumer Research, 13(3): 310-321 [13th November 2019]

Mintel, 2020. https://www.mintel.com/

Moraes, M., Gountas, J., Gountas, S. \& Sharma, P. (2019). Celebrity Influences on Consumer Decision Making: New Insights and Research Directions. Journal of Marketing Management, 35(1314): 1159-1192. [15th February 2020]. DOI: $10.1080 / 0267257 \times .2019 .1632373$.

Munnukka, J., Uusitalo, O., \& Toivonen, H. (2016). Credibility of a peer endorser and advertising effectiveness. Journal of Consumer Marketing, 33(3): 182-192. [22th December 2019]. https://doi.org/10.1108/JCM-11-2014-1221.

Nasir, N. Khan, S. Sabri, P.S.U \& Nasir, S (2016). Celebrity endorsement and consumer buying intention with mediating role of brand performance: An empirical consumer perception study in FMCG sector of Pakistan. Science International (LARHORE). 28(1): 617-624 [2th March 2020].

Neti, S. (2011). Social media and its role in marketing. International Journal of Enterprise Computing and Business Systems, 1(2): 1-15 [11st December 2019]. 
Ohanian, R. (1990). Construction and Validation of a Scale to Measure Celebrity Endorsers' Perceived Expertise, Trustworthiness and Attractiveness. Journal of Advertising, 19(3): 39-52 [23th November 2019].

Onkvisit, S. \& Shaw, J. (1987). Self-concept and image congruence: some research and managerial implications. Journal of Consumer Marketing, 4(1): 13-23.

Papista, E. \& Dimitriadis, S. (2012). Exploring consumer-brand relationship quality and identification. Qualitative Market Research: An International Journal, 15(1): $33-56$

Park, N. \& Lee, S. (2014). College students' motivations for Facebook use and psychological outcomes. Journal of Broadcasting \& Electronic Media. 601-620. DOI: $10.1080 / 08838151.2014 .966355$.

Peters, C., Shelton, J. \& Thomas, J. (2011). Self-concept and the fashion behaviour of women over 50. Journal of Fashion Marketing and Management, 15(3): 291-306. [15th February 2020].

Pradhan, D., Duraipandian, I. \& Sethi, D. (2016). Celebrity endorsement: How celebrity-brand-user personality congruence affects brand attitude and purchase intention. Journal of Marketing Communications, 22(5): 456-473. DOI: $10.1080 / 13527266.2014 .914561$.

Presidency of Council of the European Union. (2015, June 11). Proposal for a Regulation of the European Parliament and of the Council on the protection of individuals with regard to the processing of personal data and on the free movement of such data (General Data Protection Regulation). Council of the European Union. 2019]. 
https://data.consilium.europa.eu/doc/document/ST-9565-2015INIT/en/pdf

Roy, S. (2012). To Use the Obvious Choice: Investigating the Relative Effectiveness of an Overexposed Celebrity. Journal of Research for Consumers, 22: 41-69.

Sääksjärvi, M., Hellén, K. \& Balabanis, G. (2016). Sometimes a celebrity holding a negative public image is the best product endorser. European Journal of Marketing, 50(3/4): $421-44$. [21th November 2019].

Saunders, M., Philip, L. \& Thornhill, A. (2009). Research Methods for Business Students. 5 th Ed. Pearson Education Limited

Sekaran, U. \& Bougie, R. (2013). Research Methods for Business. 6th Ed. John Wiley \& Sons Ltd

Seno, D. \& Lukas A. B. (2007). The equity effect of product endorsement by celebrities. European Journal of Marketing, 41(1/2): 121 - 134. [13th November 2019].

Silvera, H. D. \& Austad, B. (2004). Factors predicting the effectiveness of celebrity endorsement advertisements. European Journal of Marketing, 38(11/12): 1509 - 1526. [21th January 2020].

Solomon, M. R. \& Rabolt, N. J. (2013). Consumer Behaviour in Fashion. Pearson Education, Inc.

Solomon, M., Bamossy, G. J., Askegaard, S. \& Hogg, M. K. (2006). Consumer Behaviour: A European Perspective. 3rd Ed. Prentice Hall.

Soneji, D., Riedel A. \& Martin, B. (2015). How Gordon Ramsay appeals to consumers: Effects of self-concept clarity and celebrity 
meaning on celebrity endorsements. Journal of Strategic Marketing, 23(5): 457-468. [19th February 2020].

Spry, A., Pappu, T. R. \& Cornwell, B. (2011). Celebrity endorsement, brand credibility and brand equity. European Journal of Marketing, 45(6): 882 - 909. [23th November 2019].

Sreejesh, S., Mohapatra, S. \& Anusree, M. R. (2014). Business Research Methods - An Applied Orientation. Springer International Publishing.

SurveyMonkey. (n.d.). GDPR And CCPA Compliance SurveyMonkey. SurveyMonkey. [11th May 2019]. https://www.surveymonkey.com/mp/privacy//mp/privacy/

Tantiseneepong, N., Gorton, M. \& White, J. (2012). Evaluating responses to celebrity endorsements using projective techniques. Qualitative Market Research: An International Journal, 15(1): 57 69. [11th November 2019].

Tesseras, L. (2016). 40-plus women: Putting age before reason. Marketing Week. [11th November 2019]. https://www.marketingweek.com/2013/03/13/40-plus-womenputting-age-before-reason/

Ticehurst, G. W. \& Veal, A J. (2005). Business Research Methods: A Managerial Approach. 2nd Ed. Pearson Education Australia

Till, D. B. \& Busler, M. (1998). Matching products with endorsers: attractiveness versus expertise. Journal of Consumer Marketing, 15(6): 576 - 586. [22th November 2019]. 
Till, D. B. \& Shimp, A. T. (1998). Endorsers in Advertising: The Case of Negative Celebrity Information. Journal of Advertising, 27(1): 67-82. https://doi.org/10.1080/00913367.1998.10673543.

Turner, G. (2014). Understanding celebrity. Sage.

Tzoumaka, E., Tsiotsou H. R. \& Soimkos, G. (2016) Delineating the role of endorser's perceived qualities and consumer characteristics on celebrity endorsement effectiveness. Journal of Marketing Communications, 22(3): p. 307-326. [22th November 2019].

UK Public General Acts. (2018, May 23). Data Protection Act 2018. Legislation Government UK. [15th May 2019]. https://www.legislation.gov.uk/ukpga/2018/12/contents/enacted

Van De Vord, R., Pinkleton, E. B. \& Epstein, E. (2008). Celebrity Endorsements and Their Potential to Motivate Young Voters. Mass Communication and Society Journal, 11(4): 420-436. [21th January $2020]$.

Van Dick, R., Van Knippenberg, D., Hägele, S., Guillaume, Y. R. F. \& Brodbeck, F. C. (2008). Group diversity and group identification: The moderating role of diversity beliefs. Human Relations, 61(10): 1463-1492. DOI: 10.1177/0018726708095711.

Wallace, E., Buil, I. \& Chernatony, L. (2014). Consumer engagement with self-expressive brands: Brand love and WOM outcomes. Journal of Product and Brand Management, 23. Dol: 10.1108/JPBM-06-2013-0326. [19th December 2019]

White, D.W., Goddard, L. \& Wilbur, N. (2009). The effects of negative information transference in the celebrity endorsement relationship. International Journal of Retail \& Distribution Management, Vol. 37(4): $322-335$. 
Wilson, J. (2014). Essentials of Business Research: A Guide to Doing Your Research Project. 2nd Ed. SAGE Publications Ltd

Wood, L. (2000). Brands and brand equity: definition and management. Management Decision, 38(9): 662-669

Wylie, C. R. (1974). The Self-concept: Theory and research on selected topics. Vol 2. University of Nebraska Press

Xiao, J. \& Li, H. (2012) Online Discussion of Sharon Stone's Comment on China Earthquake. China Media Research, 8(1): 25-39.

Zapata, S. \& Martínez-Caro, L. (2016). La influencia de la credibilidad de las celebridades en la publicidad. Anuario de Jóvenes Investigadores, 9: 240-243.

Zikmund, G. William., Babin, J. Barry., Carr, C Jon. \& Griffin, Mitch. (2010). Business Research Methods. 8th Ed. Cengage Learning. 
Which brands of cosmetics do you buy?

What factors typically encourage you to try a new cosmetic product or brand?

Celebrity endorser is described as 'any person who possess relevant public recognition and who exploits this in the interest of a consumer merchandise by featuring along with it in an ad.' Name some cosmetic brands and the celebrities who endorse them.

Where do you typically come across celebrity endorsed ads?

Have you ever felt persuaded by a celebrity endorser to purchase or test out a luxury cosmetic? If "Yes," why do you do it?

The "self-concept" is an accumulation of attitudes that people possess on themselves. It is formed up of self-esteem, overall self-evaluation of your capability, and the concept that you have of how you show to others. Centring on the "idealself" this is the image that you desire to have and the way you would like to be saw by people. Marketing experts affirm 
that costumers make purchasing decisions which adjust with their ideal-self and purchase products that bring them closer to it. Think in your ideal-self, do you believe that you purchase luxury cosmetic products to show to people yours ideal-self?

When it comes to buying luxury cosmetic products or following skincare trends, do you look to celebrities for inspiration? Or is there any other reason why you follow celebrities?

Can you think of some celebrities who you venerate for their looks and style?

Which luxury cosmetic brands would you buy that you think correspond to your ideal-self?

Congruence - So as to the celebrity endorser to be successful, brand marketers affirm that the celebrity should "be consistent" the brand they are endorsing.

\section{IMAGES (APPENDIX C)}

Which attributes would you put to describe the celebrity?

Carla Bruni

Monica Bellucci

Liv Tyler

Which attributes would you put to characterise the brand? 
Chanel

Dior

Givenchy

Which celebrity endorser would you connect to the most (particularly in style, attributes, etc.) and why?

Do you think celebrity endorsers are consistent or adjust with the brands they are endorsing?

Would you stop buying a luxury cosmetic brand if the celebrity endorser were to get involved in an unfavourable scandal? If "Yes," why?

Which attributes would you consider most significant in a celebrity endorser of a luxury cosmetic brand? And why are they important?

What would you estimate as most significant in a celebrity endorser? Appealing, expertise, or reliability. Give some reasons for your answer. 


\section{ONLINE SURVEY}

1. Which factors are important for you when choosing between cosmetic brands? (1 - Most Important, 4 - Least Important)

Price

2. Have you purchased a cosmetic brand due to a celebrity endorsing it? If "Yes," please give examples:

$\bigcirc$ Yes. Examples:

$\bigcirc$ No

3. Would you be more likely to purchase a cosmetic product if a celebrity you liked endorsed it?
$\bigcirc$ Yes
$\bigcirc$ No 
4. Which attributes in a celebrity endorser would you consider as most importantL for a luxury cosmetics brand? (1-Most Important, 3-Least Important)

\begin{tabular}{lccc} 
& 1 & 2 & 3 \\
\hline Trustworthiness & $\bigcirc$ & $\bigcirc$ & $\square$ \\
\hline Expertise & $\bigcirc$ & $\bigcirc$ & $\bigcirc$ \\
\hline Attractiveness & $\bigcirc$ & $\bigcirc$ & $\bigcirc$ \\
\hline
\end{tabular}

5. Other characteristics you think are important in a celebrity endorser for a cosmetic brand?

6. Which kind of profession in a celebrity [model, singer, actress, or realityL television star] would you be more disposed to trust when endorsing a luxuryL cosmetic product?'
Model
Singer
Actress
$\square$ Reality Television Star 
7. Are you active on social media platforms?

Facebook

8. Are you aware of any celebrities endorsing cosmetic products through socialL media? If "Yes," please give examples.

Yes. Examples:

$\bigcirc$ No

9. Have you ever been influenced to buy a cosmetic product that a celebrity hasL endorsed through a social media platform? If "Yes," please give examples.
Yes
No 
APPENDIX C: PICTURES OF CELEBRITIES

Pictures of the celebrities used in the study

RECTIFIANCE INTENSE SÉRUM

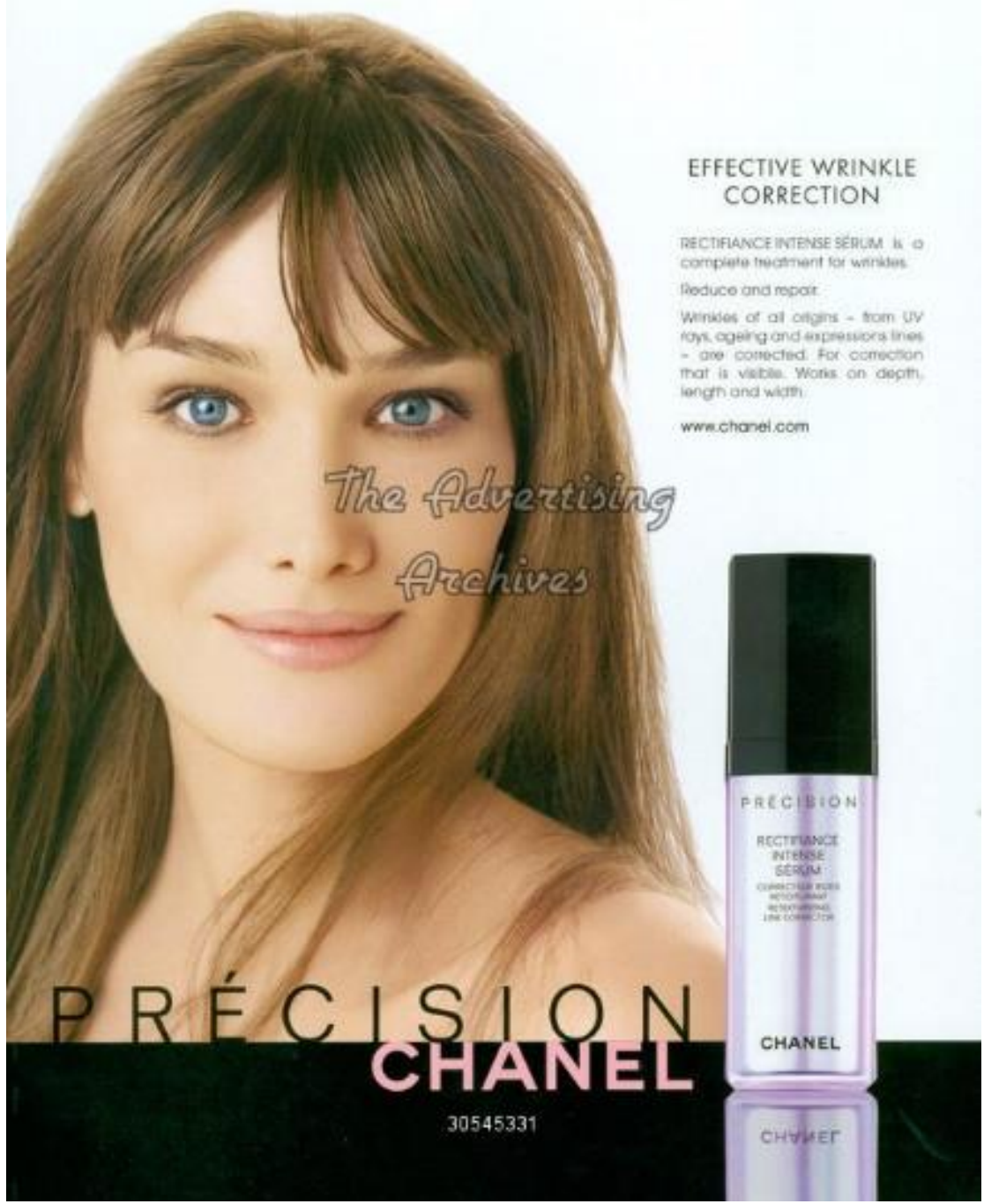

Chanel, 2005, Carla Bruni. 

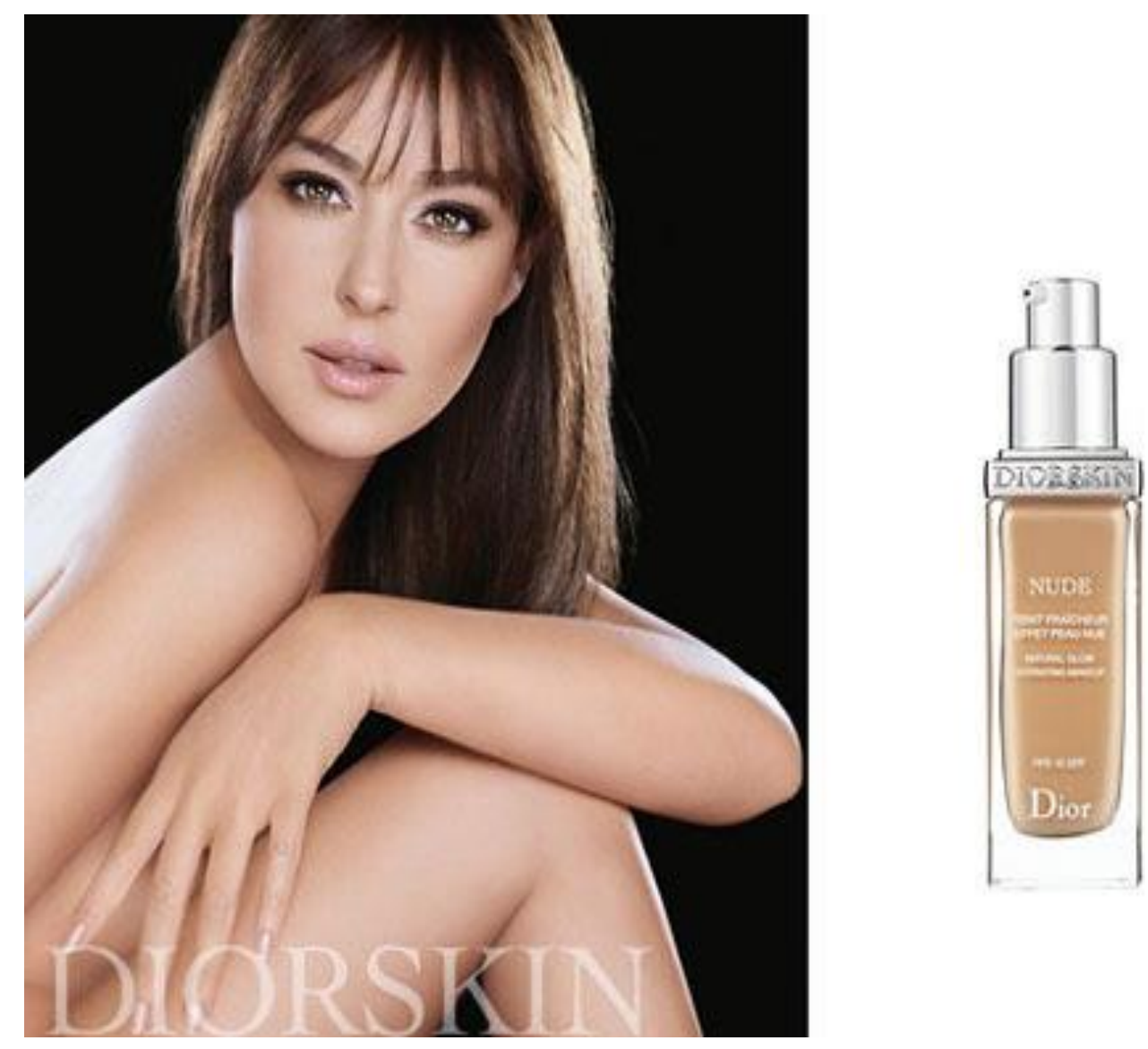

Dior, 2008, Monica Bellucci. 


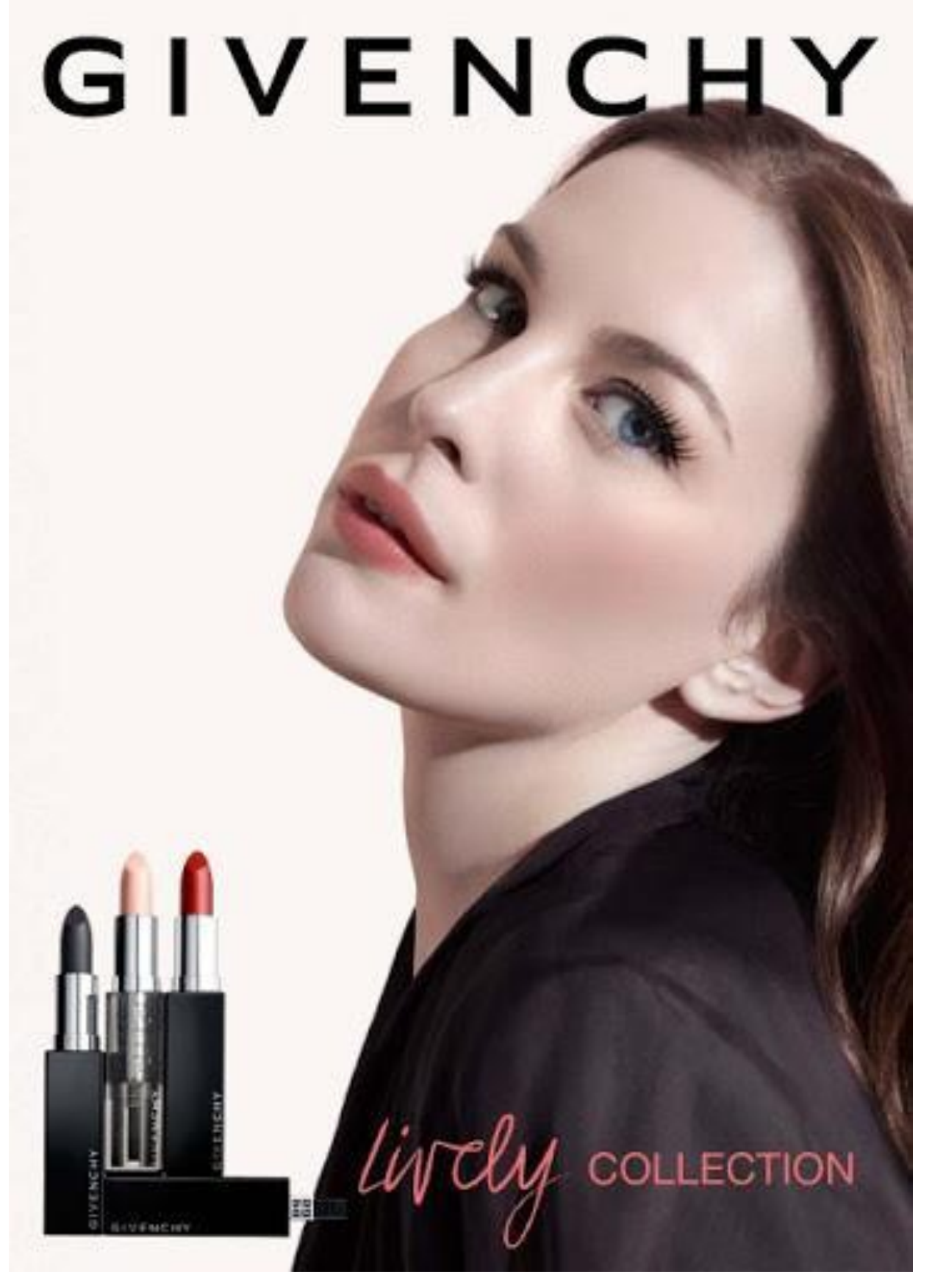

Givenchy, 2012, Liv Tyler. 
